\title{
Reexamination of Fram Strait sea ice export and its role in recently accelerated Arctic sea ice retreat
}

\author{
Jianfen Wei ${ }^{1}\left[\right.$ : Xiangdong Zhang ${ }^{2} \cdot$ Zhaomin Wang $^{3}$
}

Received: 3 September 2018 / Accepted: 20 March 2019 / Published online: 29 March 2019

(c) The Author(s) 2019, corrected publication 2019

\begin{abstract}
Using the high-resolution global ocean-sea ice model MITgcm-ECCO2, variability and changes of Arctic sea ice export through Fram Strait during 1979-2012 are examined. The simulated annual mean ice export is about $3216 \mathrm{~km}^{3} / \mathrm{year}$, which is 12.7\% of the 34-year averaged Arctic sea ice volume, with the maximum and minimum occurring in 1994/95 and 1984/1985, respectively. Winter (October-March) ice export is much more than summer (April-September) and exhibits a greater interannual variation. This study suggests that a significant regime shift of Fram Strait ice export from high to low value occurs around the mid-1990s. Further analysis shows that the regime shift of the atmospheric circulation from conventional Arctic Oscillation/North Atlantic Oscillation (AO/NAO) to the dipole-structure Arctic Rapid change Pattern (ARP) plays an important role on the regime shift of ice export. This shift of atmospheric circulation pattern dominates the variability of ice motion and changes the main source region of ice outflow. Combined with the decreased ice thickness and the less ice outflow related to the weakened northerly/northeasterly winds near the strait, sea ice export decreased, eventually generating a regime shift around the mid-1990s. The distinct impact of changes in Fram Strait ice export on the Arctic sea ice inside the basin before and after mid-1990s indicates that the recent continuing loss of Arctic sea ice was mainly induced by the accelerated ice melting in the Arctic Ocean, rather than the ice outflow through Fram Strait.
\end{abstract}

Keywords Fram Strait $\cdot$ Sea ice export $\cdot$ Regime shift $\cdot$ MITgcm-ECCO2

\section{Introduction}

The Arctic sea ice (especially multiyear ice) extent (Comiso 2012; Cavalieri and Parkinson 2012) and thickness (Rothrock et al. 2008; Kwok et al. 2009; Kwok and Rothrock 2009; Laxon et al. 2013; Lindsay and Schweiger 2015) have significantly decreased during the recent decades. These decreases have accelerated since the early 2000s

Xiangdong Zhang

xzhang9@alaska.edu

$\triangle$ Zhaomin Wang

zhaomin.wang@hhu.edu.cn

1 Polar Climate System and Global Change Laboratory, Nanjing University of Information Science and Technology, Nanjing 210044, China

2 International Arctic Research Center, Department of Atmospheric Sciences, University of Alaska Fairbanks, Fairbanks, AK 99775, USA

3 College of Oceanography, Hohai University, Nanjing 210098, China
(Comiso et al. 2008; Stroeve et al. 2012; Swart et al. 2015; Lee et al. 2017). Based on submarine, aircraft, and satellite observations, Lindsay and Schweiger (2015) found that the annual mean ice thickness shows a decreasing rate of $-0.58 \pm 0.07 \mathrm{~m} / \mathrm{dec}$ ade over the period of $2000-2012$. The decrease of Arctic sea ice has significant impacts on different aspects of climate system through, for example, altering the heat, moisture, and biogeochemical gases exchanged at the air-sea interface, and influencing the atmospheric circulation (Screen et al. 2013; Walsh 2013; Vihma 2014; Cohen et al. 2014).

To understand changes in Arctic sea ice, previous studies have investigated various aspects of sea ice mass balance associated with different forcing factors. It was found that from about the late 1980s throughout the mid-1990 s, the Arctic Oscillation (AO) (Thompson and Wallace 1998) changed from a negative to a strongly positive phase. Correspondingly, anomalous cyclonic atmospheric circulation occurred over the Arctic Ocean, resulting in an increase in heat and moisture transport into the Arctic. As a consequence, increased sea ice melt and decreased sea ice growth 
lead to a decrease in sea ice extent and thickness (e.g., Rigor et al. 2002; Zhang et al. 2003; Rigor and Wallace 2004).

Although the thermodynamic ice melting processes have greatly contributed to the changes in Arctic sea ice, dynamic ice export out of the Arctic Ocean has also been identified as a key contributing factor (Kwok 2009; Smedsrud et al. 2011; Langehaug et al. 2013), in particular for multiyear ice loss (Ricker et al. 2018). According to previous studies, the southward sea ice export across Fram Strait (the location is shown in Fig. 1) into the Greenland-Iceland-Norwegian (GIN) Sea (or Nordic Seas), which amounts to 2000-3000 km $\mathrm{km}^{3}$ per year (Serreze et al. 2006; Kwok et al. 2009; Spreen et al. 2009), comprises the largest portion of the total Arctic sea ice export (e.g., Carmack et al. 2016; Ricker et al. 2018). Part of this considerable amount of freshwater has been found flowing along the East Greenland Current into the Nordic Seas, which is closely related to the freshening of Greenland and Labrador Sea (Dickson et al. 1988; Zhang et al. 2003; Holland et al. 2006; Koenigk et al. 2006), and thus has huge impact on the global ocean circulation. The increase in Fram Strait sea ice export identified for the time period from the late 1980s to the mid1990s has been well examined, and is suggested to be driven by the changes of atmospheric circulation associated with the positive polarity of $\mathrm{AO}$ or North Atlantic Oscillation
(NAO) (Fig. 10). Specifically, during + AO/NAO years, the sea level pressure (SLP) over the Arctic is generally lower than normal, and the Icelandic Low is much stronger. Correspondingly, the Beaufort High is weakened and reduced in size, while the Transport Drift Stream is strengthened and shifted to the western side of Arctic, passing directly across the North Pole. A cyclonic anomaly of SLP and sea ice motion could be seen in the Arctic region. The associated divergence of ice motion within the basin and the synchronously enhanced cross-strait SLP gradient over the Fram Strait are both in favor of the outflow of Arctic sea ice through the strait (Fig. 11) (Kwok 2000, 2009; Hilmer and Jung 2000; Rigor et al. 2002; Zhang et al. 2003; Kwok et al. 2004). Combined with the strengthened ice melting in the Arctic Basin, total sea ice cover in the Arctic Basin decreased significantly in this time period.

Many studies have found that the atmospheric circulation in the Northern Hemisphere has substantially changed since the mid-1990s. After reaching its maximum around the winter of 1988/1989, AO/NAO index went downward to neutral and even negative phase (Overland and Wang 2005; Maslanik et al. 2007). While AO no longer follows its previous positive trend, the Arctic sea ice still demonstrates substantially accelerated declining and thinning. Based on the research of Zhang et al. (2008), the recently accelerated
Fig. 1 The Arctic Ocean and some regions mentioned in this study. Colors show the bathymetry derived from ETOPO1 (https://www.ngdc.noaa.gov/ $\mathrm{mgg} / \mathrm{global} / \mathrm{global} . \mathrm{html}$ ). The red curve indicates the vertical cross-section for calculating Fram Strait sea ice export. The black curve indicates the domain of the Arctic Basin defined in this study

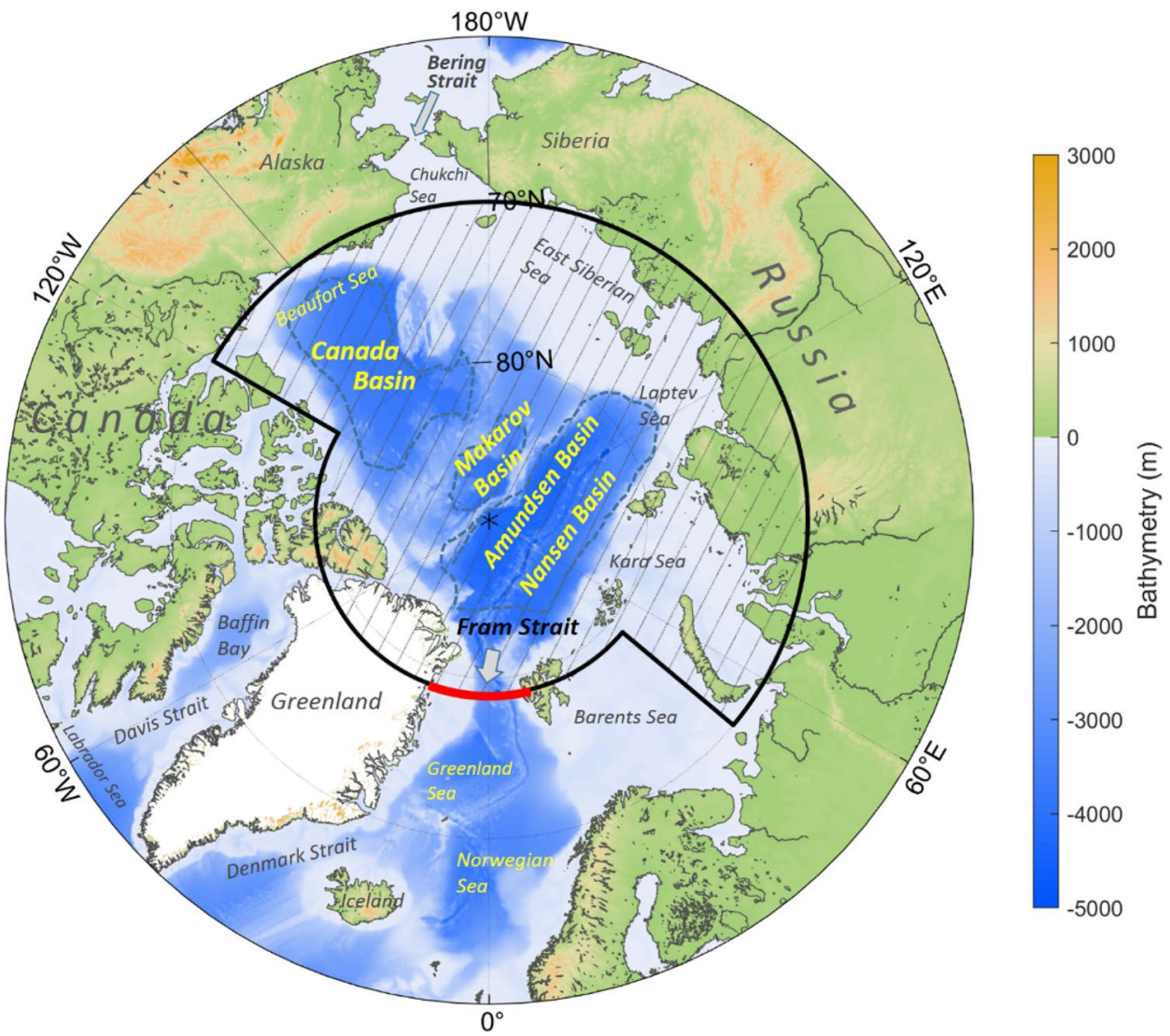


Arctic sea ice decline in both extent and thickness has been attributed to a radical spatial shift of the atmospheric circulation pattern. The main circulation pattern in the Northern Hemisphere changed from conventional tri-polar AO pattern to a totally new dipole-structure pattern during late 1990s This shift of the atmospheric circulation pattern is characterized by a hemispheric-scale, meridionally-transformed wind flow and associated enhanced poleward heat and moisture transport from either the North Atlantic or the North Pacific into the central Arctic Ocean, as was pointed out by Zhang et al. (2008).

It was suggested in previous studies that positively polarized AO could largely increase Fram Strait ice volume export (e.g., Zhang et al. 2003; Kwok et al. 2004, 2013; Kwok 2009) through the anomalous atmospheric circulation pattern. Therefore, most of these studies have also focused on this time period (from the late 1970s or late 1980s to the mid-1990s), while little study discussed the possible mechanisms of the ice export variability since then. However, following the dramatic circulation pattern shift, two scientific questions arise: how does Fram Strait sea ice export change since mid-1990s and what contribution does the changing Fram Strait sea ice export have to the accelerated sea ice decline in the Arctic Ocean in different time periods? These two questions will be addressed in this paper through a modeling study by using a coupled ocean-sea ice model.

\section{Model and data}

\subsection{Model configuration and simulation}

The model used in this study was the Massachusetts Institute of Technology general circulation model (MITgcm; Marshall et al. 1997a, b) in the state estimate configuration Estimating the Circulation and Climate of the Ocean, phase II (ECCO2): high-resolution global ocean and sea ice data synthesis. The eddy-permitting model was configured at a horizontal resolution of $18 \mathrm{~km}$ with 50 vertical levels, which could enable the model to study both small and large scale processes from ocean eddies to global circulation. The ocean model is coupled with a sea ice model that simulates a viscous-plastic rheology (Losch et al. 2010). According to the assessment by Nguyen et al. (2011), the upper cold halocline is highly consistent with observations in the western Arctic. The coupled ocean-sea ice model is run forward using optimized control parameters obtained through reducing model-data misfit by using the Green's Function approach. The control parameters include initial temperature and salinity conditions, atmospheric surface boundary conditions, background vertical diffusivity, critical Richardson numbers for the KPP (K-profile parameterization) scheme, air-ocean, ice-ocean, air-ice drag coefficients, ice/ocean/ snow albedo coefficients, bottom drag, and vertical viscosity. (Menemenlis et al. 2005a, b, 2008). Detailed description of this model and its application can be found in Menemenlis et al. (2008).

The atmospheric forcing of the model is provided from the Japanese 25-year Reanalysis (JRA-25), a cooperative research project carried out by the Japan Meteorological Agency (JMA) and the Central Research Institute of Electric Power Industry (CRIEPI) (JRA-25; Onogi et al. 2007). The spatial resolution is $1.125^{\circ} \times 1.125^{\circ}$ and the temporal resolution is $6 \mathrm{~h}$. JRA-25 reanalysis data were obtained freely from the NCAR's research data archive (https://rda.ucar. edu/datasets/ds625.0/). The initial ocean conditions were defined using a blend of the Polar Hydrographic Climatology of ocean temperature and salinity (Steele et al. 2001), the WOCE Global Hydrographic Climatology (WGHC), and the $\mathrm{ECCO} 2$ data synthesis. Detailed information of the model initialization can also be found in Menemenlis et al. (2008). The initial sea ice condition is from the Pan-Arctic Ice Ocean Modeling and Assimilation System (PIOMAS) (Zhang and Rothrock 2003). The model was then run for 34 years from 1979 to 2012, with daily output. The multidecadal, high temporal resolution model simulation results sufficiently facilitate this research, in particular considering the recent transition of the atmospheric circulation pattern over the Arctic from conventional tri-polar AO pattern to a totally new dipole-structure pattern during late 1990s, as was pointed out by Zhang et al. (2008).

\subsection{Satellite and in-situ observations of sea ice}

A number of observational data sets obtained from the National Snow and Ice Data Center (NSIDC) were used to verify the simulation results, including sea ice concentration, ice thickness, and ice drift velocity. Sea ice concentration covers a period from October 1978-present, which was derived from the Nimbus-7 Scanning Multichannel Microwave Radiometer (SMMR), the DMSP Special Sensor Microwave Imager (SSM/I), and the DMSP Special Sensor Microwave Imager and Sounder (SSMIS) Passive Microwave Data, Version 1 (abbreviated as SSM/I; Comiso 2015) (http://nsidc.org/data/NSIDC-0051). The data are generated using the NASA Team algorithm developed by the Oceans and Ice Branch, Laboratory for Hydrospheric Processes at NASA Goddard Space Flight Center. The ice thickness, available during February 2003-October 2008, was retrieved from the Ice, Cloud, and land Elevation Satellite (ICESat) Geoscience Laser Altimeter System instrument, the SSM/I, and climatologies of snow and drift of ice (Zwally et al. 2002; Schutz et al. 2005) (http://nsidc.org/data/ NSIDC-0393). The gridded fields of sea ice velocity during October 1978-present were created from an optimal interpolation of a wide variety of sensors in both gridded and 
non-gridded (raw) files, including SMMR, SSM/I, SSMIS, Advanced Microwave Scanning Radiometer-EOS (AMSRE), Advanced Very High Resolution Radiometer (AVHRR), and drifting buoys from International Arctic Buoy Programme (here also abbreviated as SSM/I; Tschudi et al. 2016). The latest version 3.0 of this merged dataset is used in this study, with the spatial resolution of $25 \mathrm{~km} \times 25 \mathrm{~km}$ in a polar stereographic projection (http://nsidc.org/data/ NSIDC-0116).

Moreover, a long-term data record of Fram Strait ice area export developed by Smedsrud et al. (2017) is also used to further verify the reliability of the model results. This dataset was constructed by using a combination of higher resolution (from 50 to $100 \mathrm{~m}$ ) satellite imagery of 2004-2014 ice drift across $79^{\circ} \mathrm{N}$ and a linear regression between ice drift speed and geostrophic wind derived from station observations of SLP difference across Fram Strait. Details can be referred to Smedsrud et al. (2017). The monthly mean time series of sea ice area export since 1935 is available here: https://doi.pangaea.de/10.1594/P ANGAEA.868944.

Figure 2 shows the climatology of Arctic sea ice concentration and ice motion velocity in March of 1979-2012. The spatial pattern of Arctic sea ice drift motion is mainly characterized by the anticyclonic Beaufort gyre and the Transport Drift Stream. Among the channels between the Arctic Ocean and other oceans, sea ice outflow through Fram Strait dominants the whole export of Arctic sea ice. The location of the vertical cross-section for calculating sea ice export through Fram Strait is marked by the red line. The section, located between northeastern Greenland and the west coast of Svalbard, is an approximately $724 \mathrm{~km}$ wide band.

\section{Simulated sea ice climate: comparisons with observations}

The 34-year simulation successfully reproduces the dramatic decrease of total Arctic (north of $60^{\circ} \mathrm{N}$ ) sea ice area in the satellite records (Fig. 3a, b). The modelled negative trends of ice area in March and September are $-1.72 \pm 0.52 \%$ and $-6.76 \pm 2.04 \%$ per decade. Compared to the SSM/I observation, the declining trend in September ice area has been underestimated (Fig. 3b), which may be induced by the insufficient summer ice melt and the relatively weaker ice-albedo feedback process in the model. As shown in Fig. 3b, the interannual variations of simulated ice area are highly consistent with SSM/I observations, with correlation coefficients of +0.69 and +0.78 for March and September, respectively (both significant at 99\% confidence level based on the Student's $t$ test). Note that these correlations are calculated with the long-term trends being removed. The two record lows of September ice area in 2007 and 2012 are also captured. Arctic sea

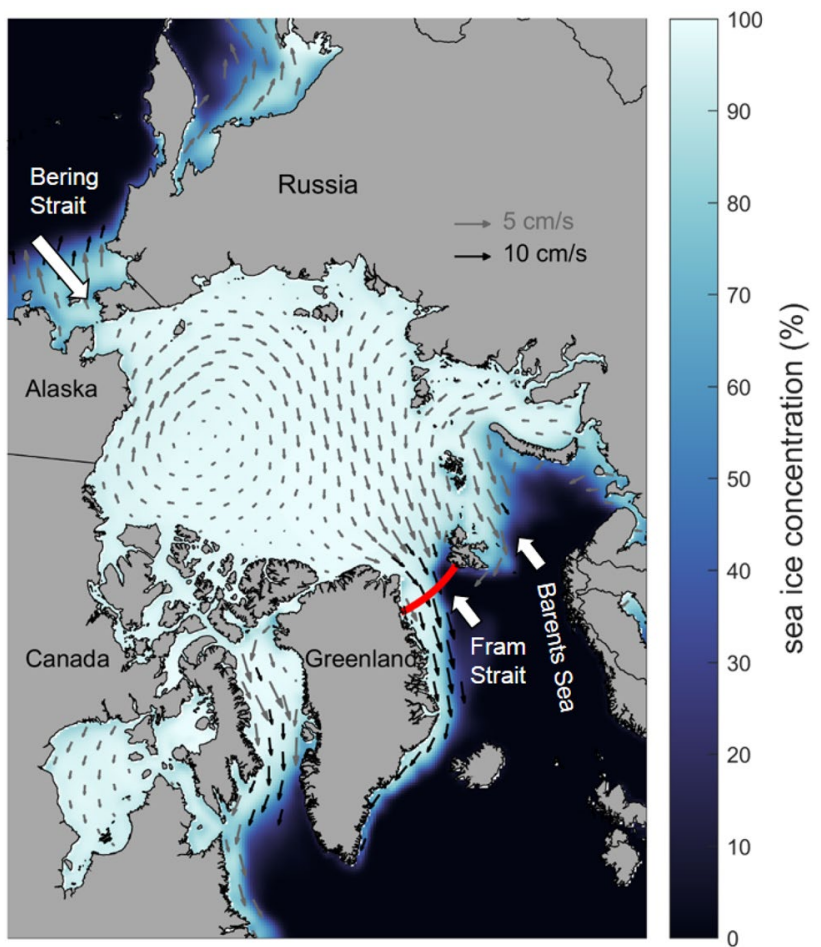

Fig. 2 Climatology of the NSIDC observed Arctic sea ice concentration $(\%)$ and sea ice motion velocity $(\mathrm{cm} / \mathrm{s})$ in March during 19792012. The red line denotes the location of the vertical cross-section $\left(78.875^{\circ} \mathrm{N}, 20.125^{\circ} \mathrm{W}-13.625^{\circ} \mathrm{E}\right)$ for calculating Fram Strait sea ice export. Note that two different scales with grey and black arrows are used

ice volume within the basin for March and September are also calculated. In this study, the domain of Arctic Basin is defined as the ocean area north of $70^{\circ} \mathrm{N}$, excluding the Nordic Seas, the Barents Sea and the Baffin Bay (Fig. 1). The decrease of the total Arctic and Arctic Basin sea ice volume are also very dramatic. As shown in Fig. 3d, the negative trends of September sea ice volume in total Arctic and the Arctic Basin are $-8.27 \pm 2.50 \%$ per decade and $-8.10 \pm 2.44 \%$ per decade, respectively. In both winter and summer season, the spatial distribution patterns of Arctic sea ice concentration and thickness are generally in agreement with the SSM/I and ICESat (2003-2008) observations, with more intensive and thicker ice located north of the Canadian Archipelago and Greenland (figures omitted). Note that in this study winter and summer season are defined as October-March and April-September, respectively. Nguyen et al. (2011) presented the assessment of the Arctic sea ice and ocean water properties from this model. By comparing model results with different available observations, the model's capability of simulating the distribution and variability of Arctic sea ice cover was proved reliable. The model's strengths and weaknesses were also assessed. A detailed assessment of the model 

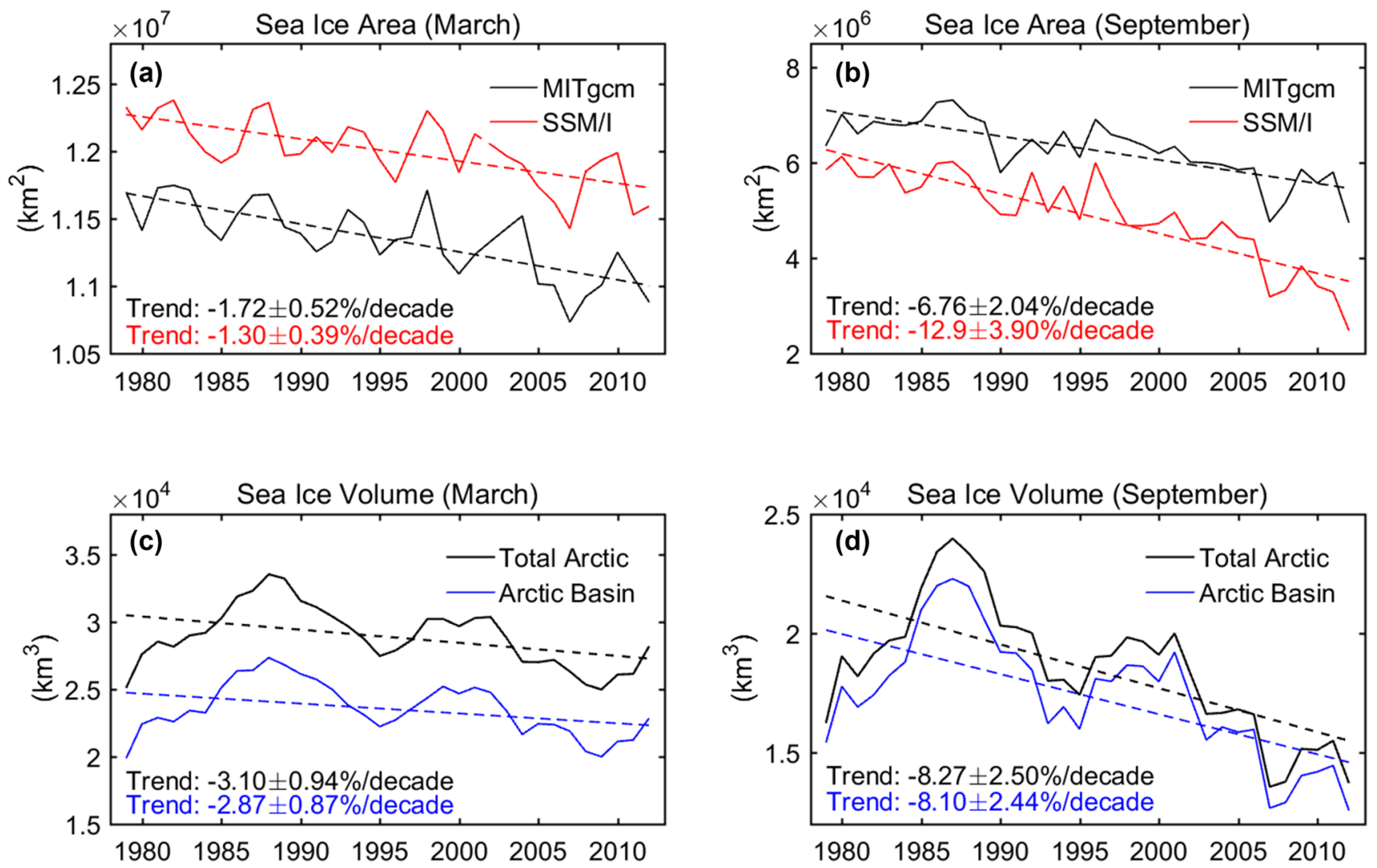

Fig. 3 Time series of the Arctic sea ice area $(\mathbf{a}, \mathbf{b})$ and volume (c, d) in both March (a, c) and September (b, d) of 1979-2012. The black and red solid lines in $\mathbf{a}$ and $\mathbf{b}$ are modeled and SSM/I observed Arctic

fidelity and the possible causes of model biases can be referred to Nguyen et al. (2011).

The model also successfully reproduces the spatial pattern of Arctic sea ice drift motion (Fig. 4). More intense ice drift occurring in March than in September could be seen in both simulation and observation results. The higher ice speed in MITgcm is presumably caused either by the model's poor performance in simulating the ice motion response to atmospheric forcing, or by the uncertainty of NSIDC merged ice motion vectors due to the discontinuity of different sensors.

Figure 5 shows the time series of spatially averaged winter (October-March) ice drift speed anomaly inside the Arctic Basin. Both the simulation and the observation demonstrate a positive trend of basin-wide Arctic ice drift speed since $1984 / 85$, although the simulated trend $(7.21 \pm 2.20 \% /$ decade) is much weaker than observation $(35.30 \pm 10.76 \% /$ decade). This positive trend is in consistence with previous studies (e.g., Hakkinen et al. 2008; Rampal et al. 2009; Spreen et al. 2011). The reinforced ice motion is either attributed to the increase of local Arctic storm activity caused by the poleward shift of the storm track (Zhang et al. 2004; Hakkinen et al. 2008), or to the recently enhanced

sea ice area, respectively. The black and blue solid lines in $\mathbf{c}$ and $\mathbf{d}$ are modeled sea ice volume in total Arctic and Arctic Basin, respectively

mobility and fracture of Arctic sea ice following the retreat and thinning of ice cover (Rampal et al. 2009; Spreen et al. 2011). Thus it might be noted that the variability of Arctic sea ice motion speed is spatially dependent due to the local impacts of atmospheric forcing, ocean circulation, and the associated sea ice cover condition. Note that the amplitude of observed ice speed is much smaller than simulation before the year 1983/84. This is probably caused by issues related to model initialization, or by the incompatibility between satellite-based ice motions derived from different sources. As pointed out by Bi et al. (2016), sea ice drift velocity may be underestimated before July 1987 due to the lower spatial and temporal (every other day) resolution of SMMR 37-GHz data.

The realistic simulations of Arctic sea ice climatology largely lay fundamental basis and ensure credibility for us to analyze variability of and changes in Fram Strait sea ice export though some biases still exist. In this study, sea ice volume export is the product of sea ice area, thickness and drift velocity perpendicular to the vertical cross-section for the grid cells along the section, while sea ice area export is only the product of ice area and drift velocity. Daily sea ice volume export was computed from the product of daily sea 

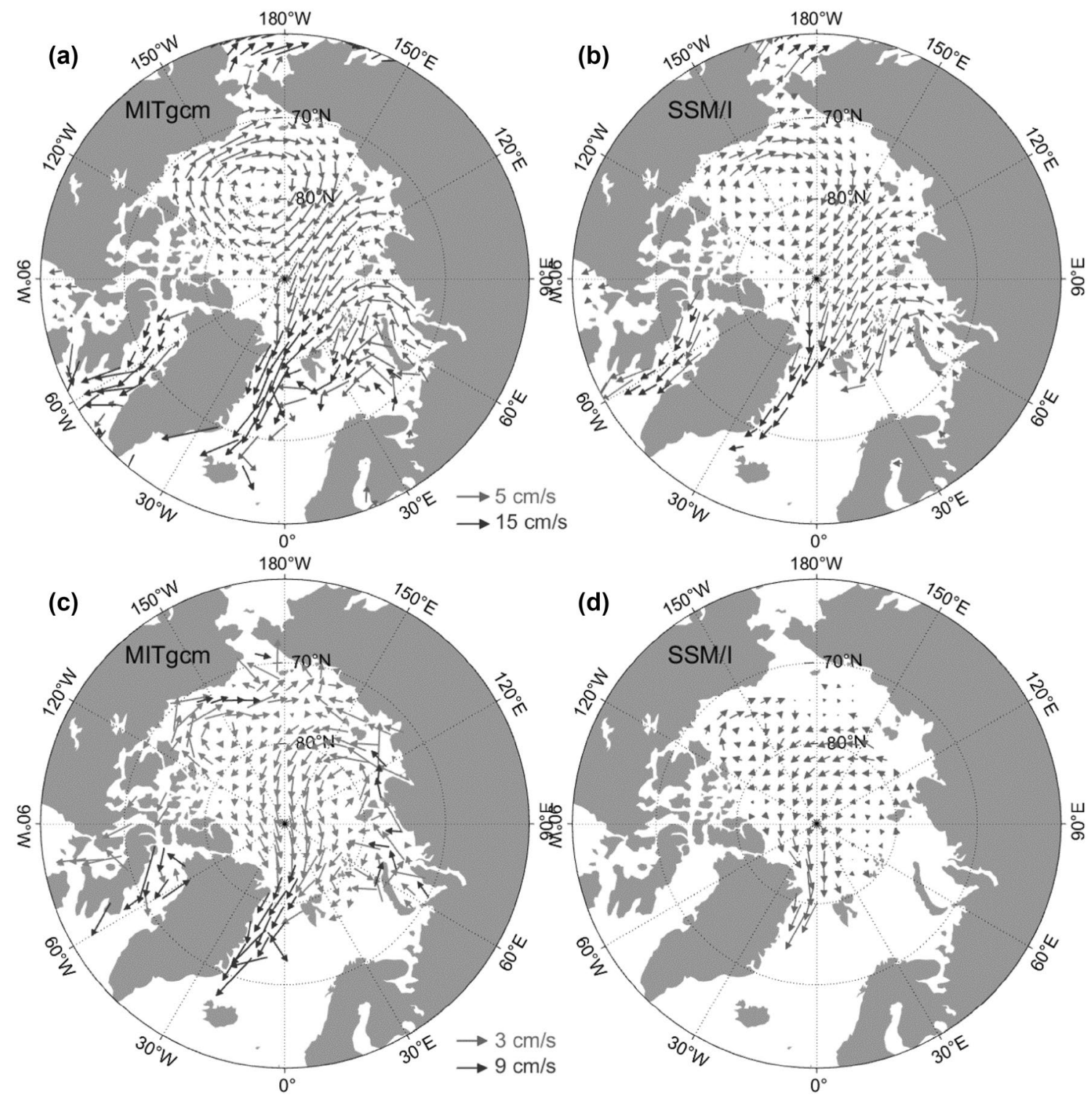

Fig. 4 Climatology of a simulated and b observed Arctic sea ice motion in March during 1979-2012. c, $\mathbf{d}$ Are the same as a and b, but for September. Note that two different scales with grey and black arrows are used

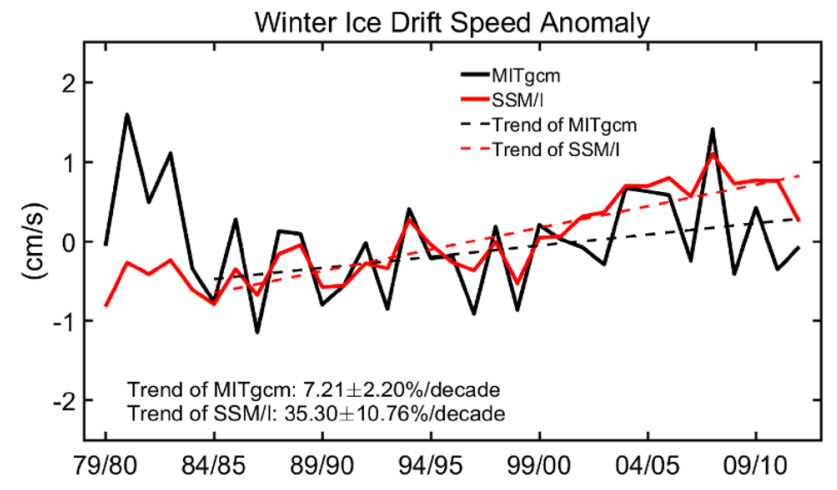

Fig. 5 Spatially averaged winter (October-March) sea ice drift speed anomaly within the Arctic Basin ice concentration, thickness, and ice motion velocity across the vertical section as shown in Fig. 1. Monthly, seasonal, and annual ice volume export were then obtained as the sum of the daily export for the defined time periods. The high temporal resolution of the model outputs makes it possible to examine multi-time scale variability of Fram Strait sea ice export.

At first, seasonal cycle (Fig. 6) and interannual variation (Fig. 7) of simulated ice area and volume export were compared with observations. For consistency, sea ice data from NSIDC has been linearly interpolated to the model grid during the calculation of ice export. For the comparison of ice area export, both results derived from NSIDC merged ice concentration and ice motion (abbreviated as 

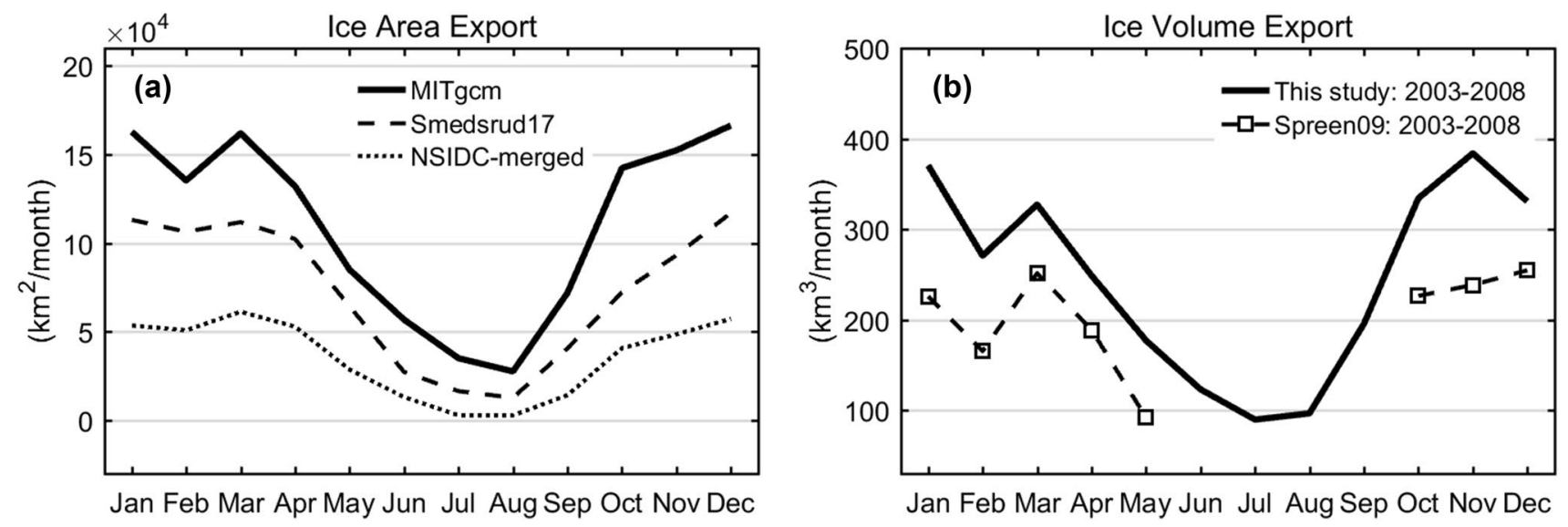

Fig. 6 Seasonal cycle of modeled and observed sea ice a area export and b volume export during 1979-2012 and 2003-2008, respectively
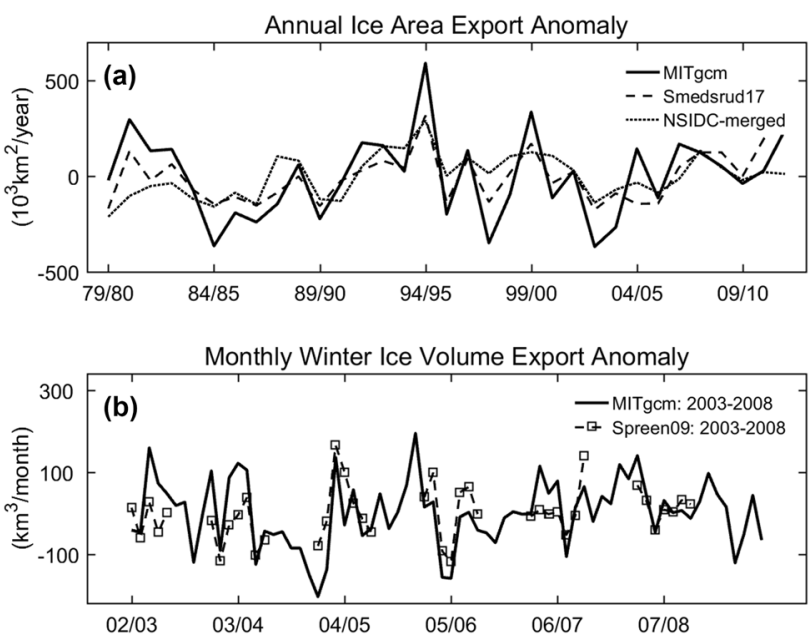

Fig. 7 a Annual (October-September) ice area export anomaly from 1979/1980-2011/2012. b Monthly winter (October-April) ice volume export anomaly from 2002/2003-2007/2008

NSIDC-merged) and from Smedsrud et al. (2017) (abbreviated as Smedsrud17) were used. We also used the 2003-2008 monthly winter ice volume export from Spreen et al. (2009) (denoted as Spreen09), which was obtained by combining two ICESat measurement periods per year with an average seasonal cycle of sea ice thickness from moored Upward Looking Sonar (ULS) measurements (Vinje et al. 1998). Details can be found in Spreen (2008) and Spreen et al. (2009).

Figure 6 shows that the seasonal cycle of modeled ice export is highly consistent with observations. Summer (April-September) ice area or volume export is typically lower than in winter (October-March). As pointed out by Kwok et al. (2009), the apparently lower summer ice export is due to the lower SLP gradients across the strait and the lower multiyear ice fraction in the strait during summer

months. Those multiyear ice even could not reach Fram Strait in some years. For sea ice area export, model result is much higher than NSIDC-merged and slightly higher than Smedsrud17. The relatively high ice export from model may primarily result from the overestimation of sea ice drift speed within and near the strait. However, it is speculated that the coarse spatial resolution $(25 \mathrm{~km} \times 25 \mathrm{~km})$ and the inconsistency of different sensors or observation measurements used in generating the merged NSIDC ice data is likely to cause great uncertainty in computing ice export. Krumpen et al. (2016) also pointed out that the ice area export derived from NSIDC ice data shows unrealistic high values than those based on SAR images and SLP gradients (see their Fig. 7). Thus the difference of ice area export between MITgcm and NSIDC-merged is much larger than that between MITgcm and Smedsrud17 (Fig. 6a).

In this study, the interannual to decadal variability of ice export through Fram Strait is the main focus. Thus here the anomaly rather than the magnitude of Fram Strait ice export is more concerned. As is shown in Fig. 7a, the interannual variability of modeled ice area export is much closer to Smedsrud17 than to NSIDC-merged for the whole study period. The correlations between simulated ice area export and the estimation from Smedsrud17 and NSIDC-merged are +0.81 and +0.55 , respectively, both significant at $99 \%$ confidence level. With the fine time continuity and high spatial resolution, results from Smedsrud17 are supposed to be more credible than those from NSIDC. Besides, the simulated ice area export is also very close to the estimation derived from the $12.5 \mathrm{~km} \mathrm{SSM} / \mathrm{I} 85-\mathrm{GHz}$ channel in Kwok (2009) (see their Fig. 3) during 1992-2007. The high consistency between the simulation and the high-resolution observations could sufficiently prove the reliability of model results analyzed in this study. In addition, a slightly positive trend of modeled ice area export $(+1.21 \pm 0.36 \%$ per decade) was detected during 1979-2012, although it is lower 
than the trend in Smedsrud17 $(+5.57 \pm 1.68 \%$ per decade $)$. Smedsrud et al. (2017) pointed out that this increasing trend of ice area export is largely related to the strengthening of the southward ice drift motion in winter, which is induced by the strengthened winter geostrophic wind over the strait. Similar conclusions are also found in this study. During the past three decades, annual mean sea ice concentration along the zonal section within the strait has slightly decreased (figure omitted), while the meridional southward ice velocity has increased at a rate of about $0.13 \mathrm{~cm} / \mathrm{s}$ per decade due to the increasing trend of annual northerly wind speed along the section (about $+0.19 \mathrm{~m} / \mathrm{s}$ per decade). The positive trend of ice area export in summer $(+2.26 \%$ per decade $)$ is larger than that in winter $(+0.7 \%$ per decade $)$, which is also in consistent with the study of Smedsrud et al. (2017), although the trends are much lower than those from Smedsrud17. Based on the simulation results of CMIP5 models, Langehaug et al. (2013) found that 10-18\% of the sea ice covered Arctic Basin is annually exported, which is similar to the result in this study (18.6\%). As shown in Fig. 7b, a great agreement exists between simulated and observed 40-months winter (October-April of 2003/2004-2007/2008 and January-May of 2003) ice volume export anomaly. A high correlation coefficient of +0.62 , significant at $99 \%$ confidence level, exists between the two time series. The consistent interannual variability of simulated ice volume export with observation again provides a solid foundation for the subsequent analysis. The averaged ice volume export from MITgcm and Spreen09 are $321.14 \mathrm{~km}^{3} /$ month and $216.88 \mathrm{~km}^{3} /$ month for the 40-month winter period, respectively. Similar to the case of sea ice area export, the overestimations of sea ice drift velocity and sea ice thickness within and near the strait may mainly result in the overestimation of simulated sea ice volume export. From here on, ice volume export will be referred to as ice export.

\section{Variability and changes of Fram Strait sea ice export and the attributions}

\subsection{Regime shift in Fram Strait sea ice export}

The realistic simulations of Arctic sea ice climatology largely lay fundamental basis and ensure credibility for us to analyze variability of and changes in Fram Strait sea ice export though some biases still exist. Figure 8a shows the simulated daily ice export in 2006/07, which showed high variability throughout the year because of the strong dependence of sea ice motion on synoptic atmospheric forcing. Annual, winter and summer ice export during 1979-2012 are shown in Fig. 8b. On average, the simulated annual ice export of about $3216 \mathrm{~km}^{3}$ was largely attributed to winter export (which carries $66.0 \%$ of total annual export). The
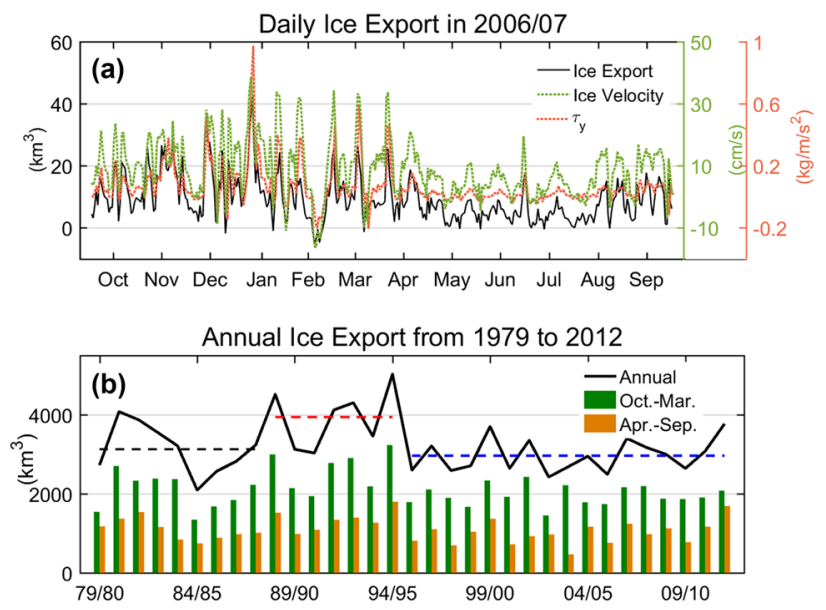

Fig. 8 Simulated a daily ice export in the year of 2006/2007 and b annual (October-September) ice export from 1979/1980-2011/2012. In a, the dotted green and red lines denote averaged daily meridional ice velocity and meridional surface wind stress along the vertical cross-section. In $\mathbf{b}$, the black line, green and orange bars denote annual, winter (October-March) and summer (April-September) ice export, respectively. The black, red and blue dashed lines show the mean value of annual ice export during 1979/1980-1987/1988, 1988/1989-1994/1995 and 1995/1996-2011/2012, respectively

annual amount of ice export is about $12.7 \%$ of the 34 -year averaged annual Arctic sea ice volume, and is about $15.2 \%$ of the annual sea ice volume within the basin. In addition, the larger standard deviation of winter export suggests higher interannual variation than in summer. The modeled minimum and maximum annual ice export occurred in $1984 / 1985$ and 1994/1995. The maximum was also detected by Vinje et al. (1998) and Kwok et al. (2004), although these studies were based on different observations with different study periods of 1990-1996 and 1991-1998, respectively. Based on modeled ice thickness from PIOMAS, this unique largest ice export in 1994/1995 was also found by Zhang et al. (2017). Note that the quantities about sea ice export should be considered with great prudence, since distinct differences exist between results in this study and results from previous studies based on varied ice motion, ice thickness and ice concentration datasets.

Most interestingly, both the annual and seasonal ice export exhibited two significant "regime shifts" around 1987/1988 and 1994/1995, respectively (Fig. 8b). Ice export during 1988/1989-1994/1995 is much more than before until reaching its maximum. After this maximum, ice export substantially decreased and fluctuated year-by-year without any visible trend. On average, the mean annual ice export was about $3127 \mathrm{~km}^{3}$ from 1979/1980-1987/1988, about $3940 \mathrm{~km}^{3}$ from $1988 / 1989-1994 / 1995$, while it was only about $2965 \mathrm{~km}^{3}$ from 1995/1996-2011/2012. Using Student's t-test, both of these two regime shifts in annual or seasonal 
ice export are proved to be significant at $95 \%$ confidence level. The regime shifts of annual ice export in $1987 / 1988$ and $1994 / 1995$ are even significant at $99 \%$ confidence level. Moreover, the difference of standard deviation in annual ice export before and after mid-1990s (1979/1980-1994/1995 minus 1995/1996-2011/2012) is about $369 \mathrm{~km}^{3}$, amounting to $11.5 \%$ of the mean export during the whole period. Obviously, the abrupt increase in ice export since $1988 / 1989$ is closely related to the phase evolution of AO from negative to strongly positive, and has been investigated by previous studies (e.g., Kwok et al. 2004; Kwok 2009). Thus the second regime shift is the main focus in this study. Note that there is no necessary connection between the regime shift of ice export and its long-term trend in a certain range of time. In this study, the linear trend in annual ice export is insignificant during 1979-2012 or in any separated time period, while the difference of mean ice export between either two time periods shown in Fig. 8b is quite remarkable.

To understand the characteristics of the variability and changes, in particular the regime shift of Fram Strait ice export, the three contributing factors to the ice export were first analyzed, including ice concentration, ice thickness and meridional ice drift velocity across the strait. Here we only focused on winter considering the greater interannual variation of ice export in this season. It was found that both the meridional ice drift velocity and ice thickness were highly correlated with the amount of ice export during 1979-2012. The correlation coefficients are +0.73 and +0.59 , respectively, both significant at $99 \%$ confidence level (Fig. 9b, c. Note that the sign of the meridional ice velocity is reversed in Fig. 9b). The high correlation may suggest that the interannual variability of sea ice volume export is mainly contributed by the variability of both ice meridional drift speed and ice thickness within the strait. This conclusion is largely consistent with the study of Lindsay and Zhang (2005). Sea ice concentration, however, showed a relatively weak relationship with the ice export, with a correlation coefficient of only +0.25 (Fig. 9a).

We can readily find a substantial decrease of the crosssection sea ice thickness within Fram Strait after 1994/1995 in Fig. 9c. The ice thickness is reduced by about $25.0 \%$ (passing 95\% confidence level) from 1988/1989-1994/1995 to $1995 / 1996-2011 / 2012$, which may directly induce the regime shift of Fram Strait ice export shown in Fig. 8b. By comparison, the meridional ice velocity across the strait show no obvious difference between these two periods. Thus the sea ice drift velocity appears to be related to interannual variability of sea ice volume export, whereas sea ice thickness appears to be more related to a longer-term variability.

However, changes of basin-wide sea ice drift pattern may dramatically determine the thickness of sea ice flowing into Fram Strait, which may jointly influence the variability and
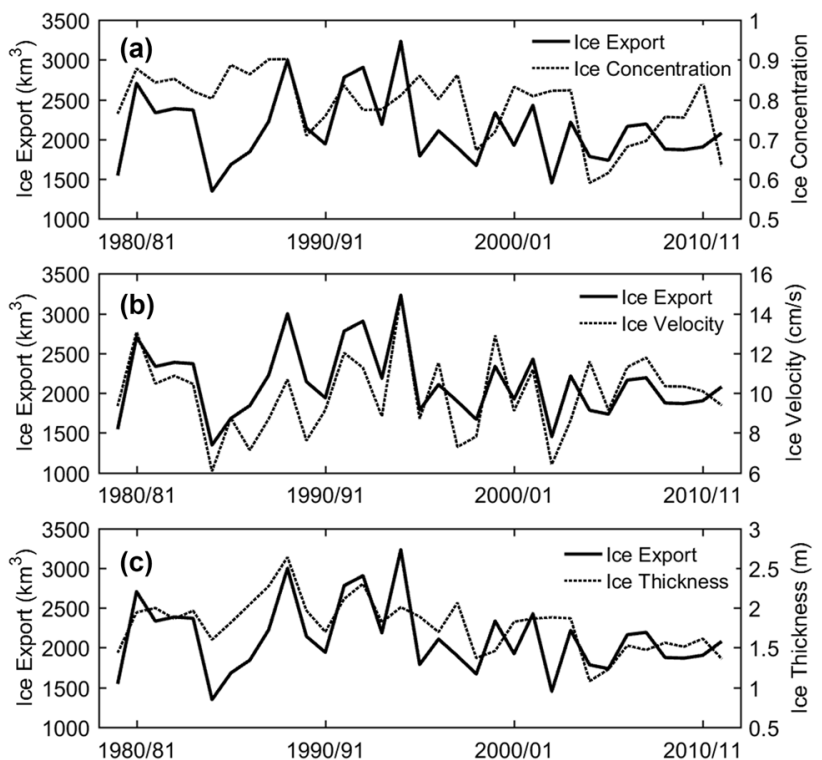

Fig. 9 Simulated winter a ice concentration, $\mathbf{b}$ ice meridional velocity and $\mathbf{c}$ ice thickness at the vertical section across Fram Strait during 1979/1980-2011/2012. The black solid lines are winter sea ice volume export. The sign of the meridional ice velocity in $\mathbf{b}$ is reversed

changes of total ice export on long-term time scale. The linkage between them will be discussed in the next section.

\subsection{Attributions of the regime shift in Fram Strait sea ice export}

As mentioned above, basin-wide Arctic sea ice drift pattern could largely determine the thickness of sea ice flowing into Fram Strait and eventually influence the amount of Fram Strait sea ice export. Previous studies have attributed the major variability and changes of sea ice motion within the Arctic Basin and going through Fram Strait to the forcing effect from the alteration of large-scale atmospheric circulation. In this study, positively polarized AO from 1988/1989 to mid-1990s (Fig. 10b) is associated with anomalous cyclonic wind pattern over the Arctic, which enhances sea ice outflowing from central Arctic Ocean into Fram Strait and increases total Fram Strait ice volume export (Fig. 11).

It is obvious in Fig. 10b that AO has shifted from persistent negative or positive phases to more neutral and unstable phases after the mid-1990s, which has been confirmed by previous studies (Zhang et al. 2008; Day et al. 2012; Kwok et al. 2013). The conventional annular AO pattern has recently been replaced by a new dipole anomaly pattern in the Northern Hemisphere (Zhang et al. 2008; Overland and Wang 2010). Zhang et al. (2008) investigated the occurrence of the new pattern and defined it as the "Arctic Rapid change Pattern" (ARP). Specifically, the running EOF method was used onto the SLP fields in each time 

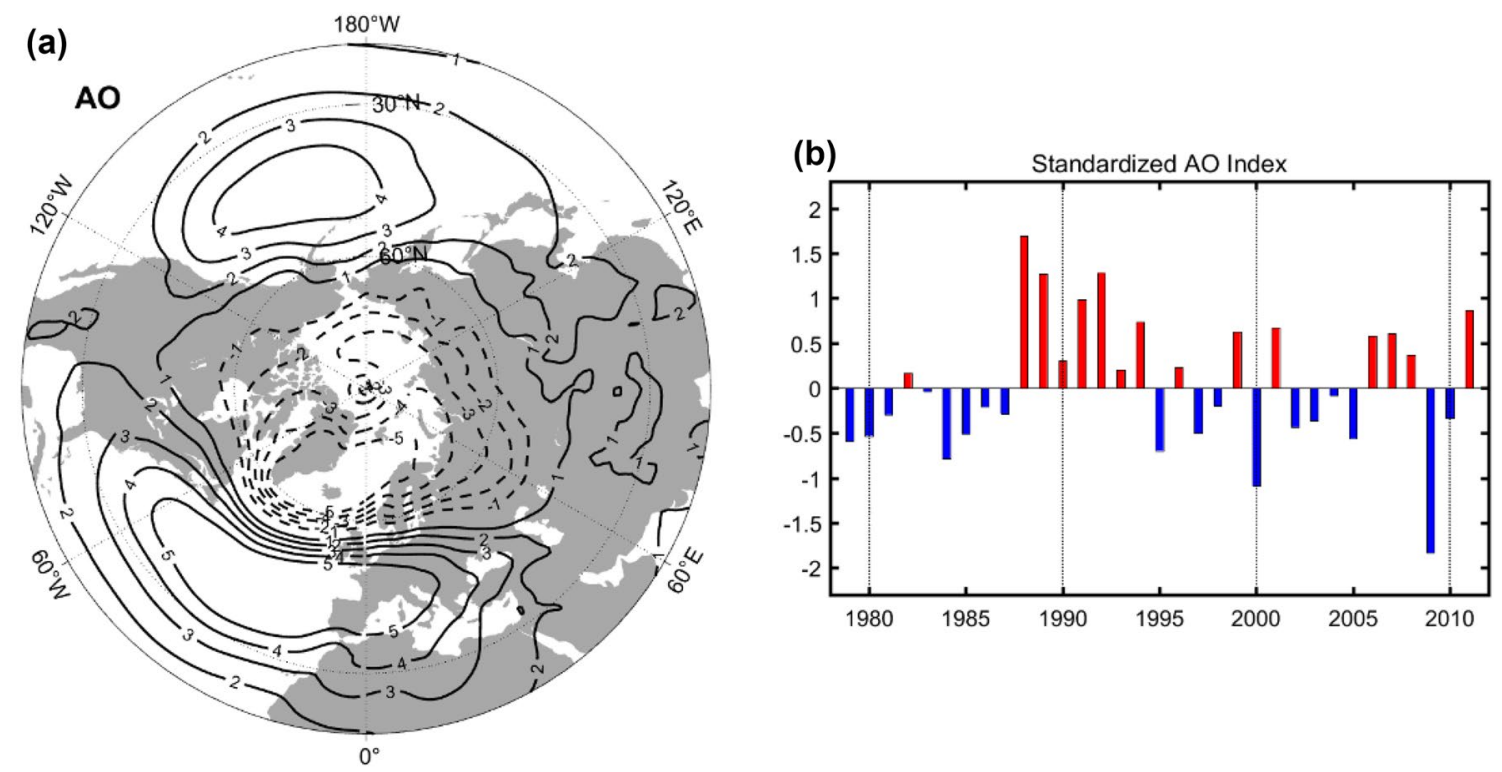

Fig. 10 The spatial pattern of the a Arctic Oscillation (AO) and the b standardized winter (October-March) AO index during 1979-2012
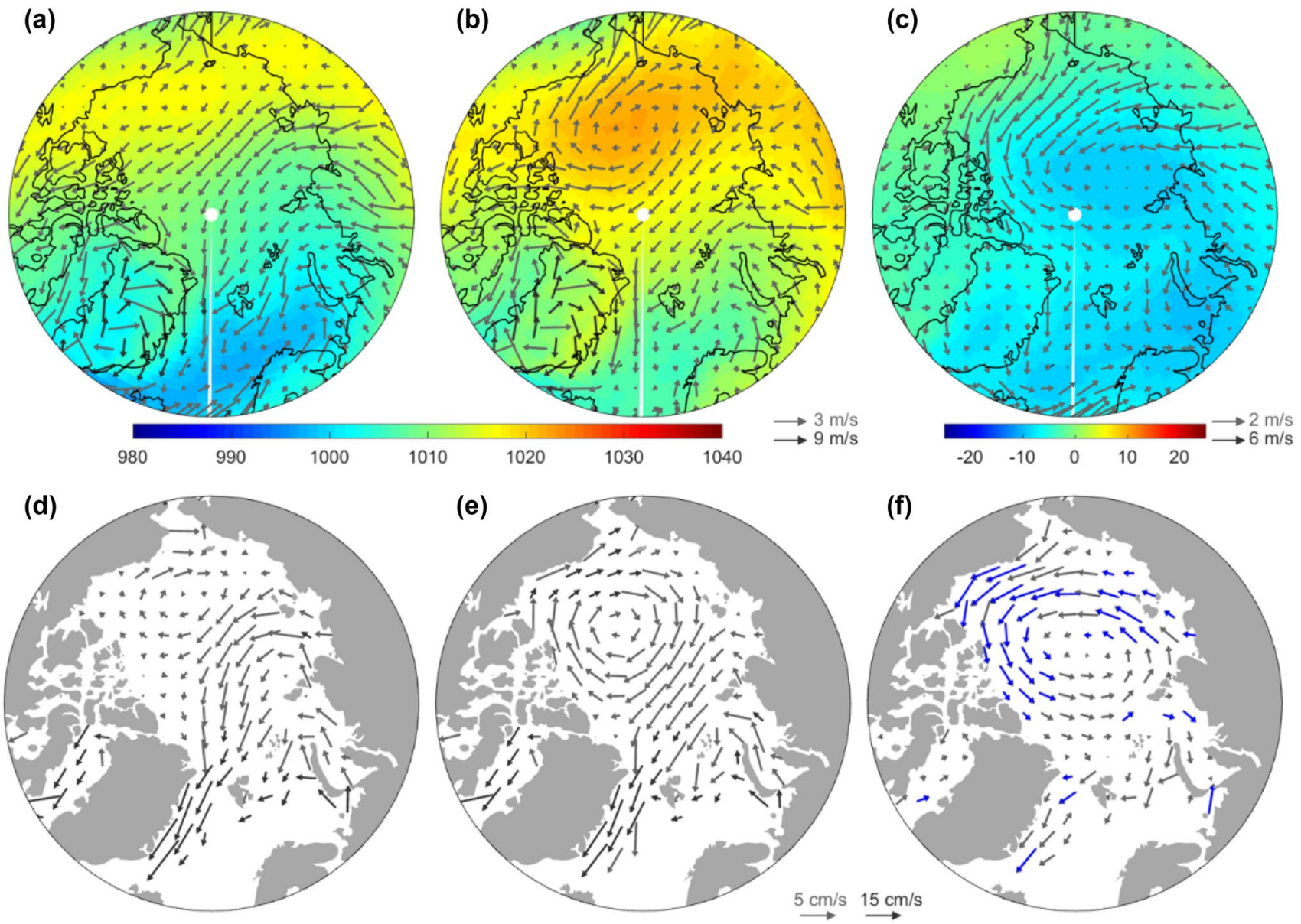

Fig. 11 Composite fields of winter (October-March) $10 \mathrm{~m}$ wind (vectors) and SLP (colors) for years of $\mathbf{a}+\mathrm{AO}, \mathbf{b}-\mathrm{AO}$ and $\mathbf{c}$ their difference (a, b) during 1979/1980-1994/1995. d-f Are the same as a-c, but for winter ice motion. The unit of the scale bar in $\mathbf{a}-\mathbf{c}$ is $[\mathrm{hPa}]$. Blue vectors in $\mathbf{f}$ are the differences of ice motion speed significant at $90 \%$ confidence level 
window. The time windows is defined as a 30-month running wintertime window, which includes five consecutive years with each containing 6 months from October-March. As shown in Fig. 12, the tri-polar structure of AO robustly represented the dominant atmospheric circulation pattern before 2001/2002-2005/2006. However, the centers of action of AO pattern were continuously shifting with time, eventually leading to an end of the persistence of this pattern in 2001/2002-2005/2006. In this time period, an abrupt northeastward shift (from the northeastern Nordic Seas to the Eurasian Arctic coast) of the poleward center of action occurred. The leading EOF spatial pattern was replaced by the new dipole-structure ARP pattern, with its two centers located in the Eurasian Arctic coast and North Pacific, respectively. Zhang et al. (2008) comprehensively examined its role in drastic changes of Arctic climate system, including the record low Arctic sea ice cover in summer of 2007. Detailed description of this pattern and its role in the changing Arctic climate system can be referred to Zhang et al. (2008).

We estimated the correlation between winter (October-March) ARP index and winter ice export from $1979 / 1980$ to $2011 / 2012$ and found they were highly correlated throughout the study period (Fig. 13), with a high correlation coefficient of +0.70 (which is significant at $99 \%$ confidence level). In addition to the strong interannual

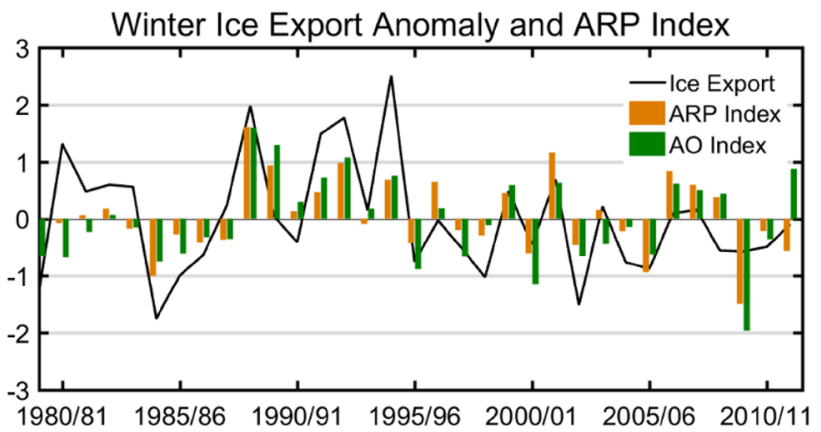

Fig. 13 Simulated normalized winter (October-March) sea ice export and the ARP as well as AO index since 1979/1980

correlation, it is necessary to examine if a connection exists between ARP index and sea ice export related to the regime shift in the ice export. It is obvious from Fig. 13 that the phase shift of ARP index is very similar to AO, with negative state in 1979/1980-1987/1988, positive state in 1988/1989-1994/1995, and an oscillatory but mostly negative state since 1994/1995. It could be known from the above description of ARP that the ARP pattern is kind of a result when the location and strength of action centers of AO change with time. That is the possible reason for the similar shapes between AO index and ARP index. Considering
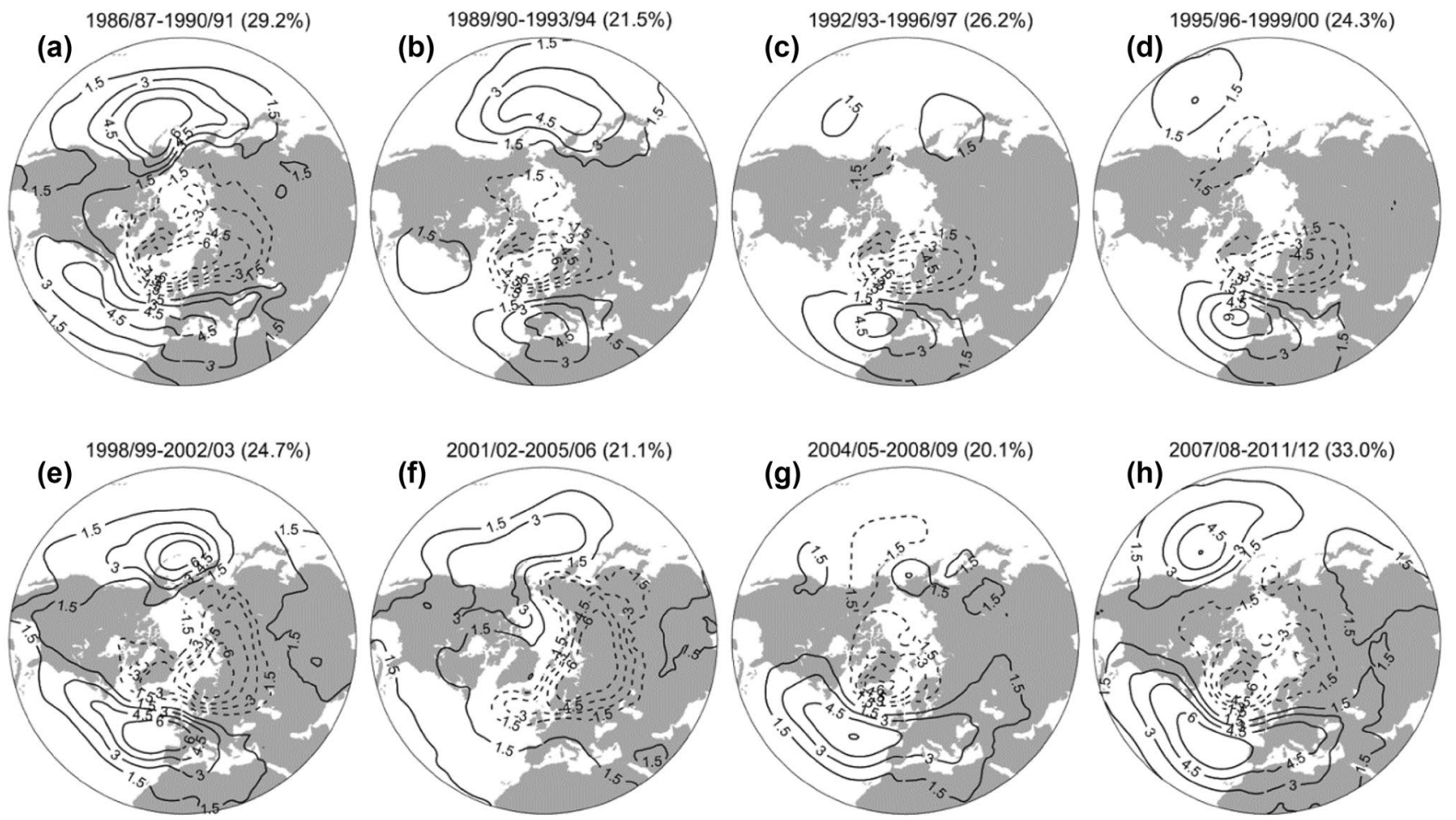

Fig. 12 The first EOF spatial patterns of SLP north of $20^{\circ} \mathrm{N}$ in each 5-year time windows during 1986-2012. The percentage in each sub-graph represents the explained variance of the leading EOF mode in each time window 
these changes of ARP phase, here the test of phase shift is done for ARP index during 1988/1989-1994/1995 and 1995/1996-2011/2012. The result shows that the phase shift of ARP index is also very significant (passing 99\% confidence level), indicating its close relationship with the shift of Fram Strait sea ice export.

To confirm the influences of the changing atmospheric circulation onto the regime shift of Fram Strait ice export, the composite fields of $10 \mathrm{~m}$ wind, SLP and Arctic sea ice motion in winters with positive $(1996 / 1997,1999 / 2002$, 2001/2002, 2006/2007 and 2007/2008) and negative (2000/2001, 2005/2006, 2009/2010 and 2011/2012) ARP indices (using the criterion of 0.7 standard deviation) since mid-1990s were calculated. Sea ice thickness in the two composite fields showed no significant difference in the Arctic Ocean and thus are not given here. In positive ARP years, the anticyclonic circulation was limited to the Beaufort Sea, and the ice outflowing into the Nordic Seas was from both the central Arctic and the East Siberian Sea and
Laptev Sea (where thick ice is concentrated) driven by the wind from the Pacific sector and from the Eurasia (Fig. 14a, d). In negative ARP years, the anticyclonic circulation over the Beaufort Sea was expanded and strengthened, while the northerly and northeasterly winds in northeast of Fram strait (north of Svalbard and northern Barents Sea) were weakened and shifted to easterly. The ice drift following the Transpolar Drift Stream was weakened and shifted to the Laptev Sea and Kara Sea. Consequently, less ice from the central Arctic were exported through the strait (Fig. 14b, e). The difference maps of $10 \mathrm{~m}$ wind and ice motion between negative and positive ARP winters (Fig. 14c, f) demonstrate that the anomalous northward ice motion near the strait and across the Arctic Basin was closely related to the anomalous southerly wind during-ARP winters. Since ARP transitions to a generally, decadal-scale negative phase after 1995/1996 with more frequent occurrence of large negative polarity (Fig. 13), the total Fram Strait sea ice export decreased correspondingly. (a)

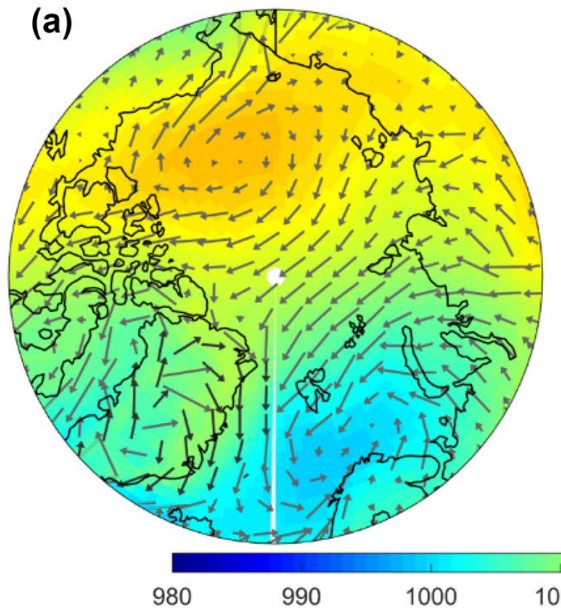

980

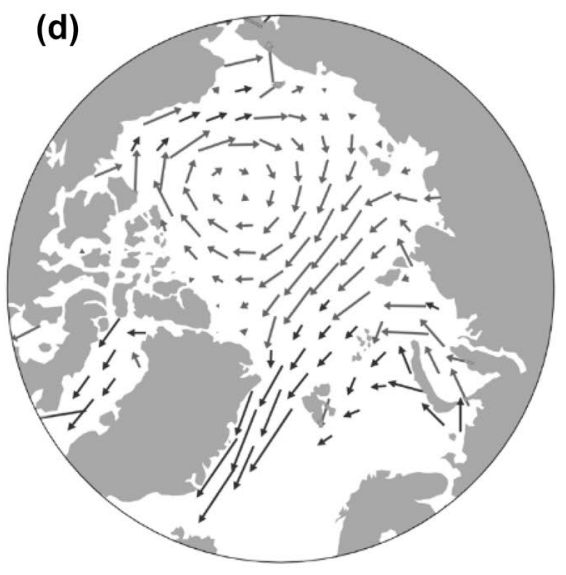

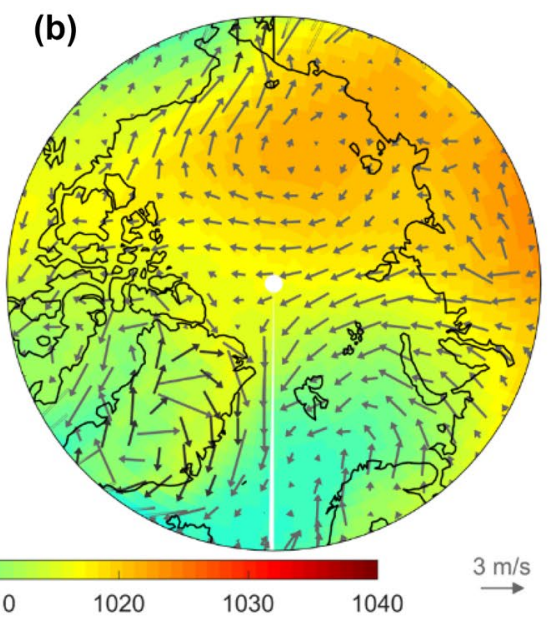

(e)

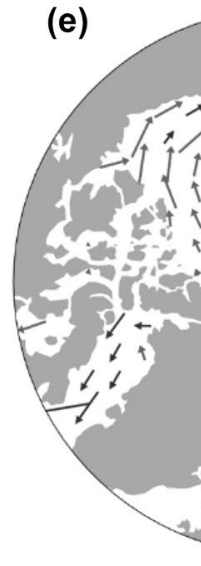

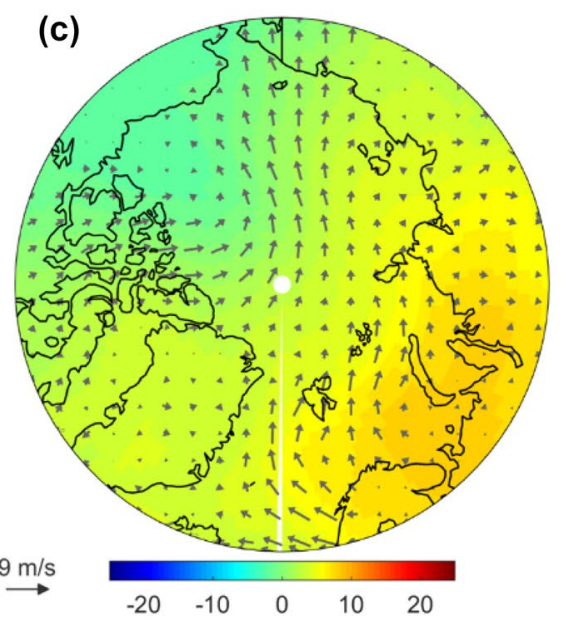

(f)

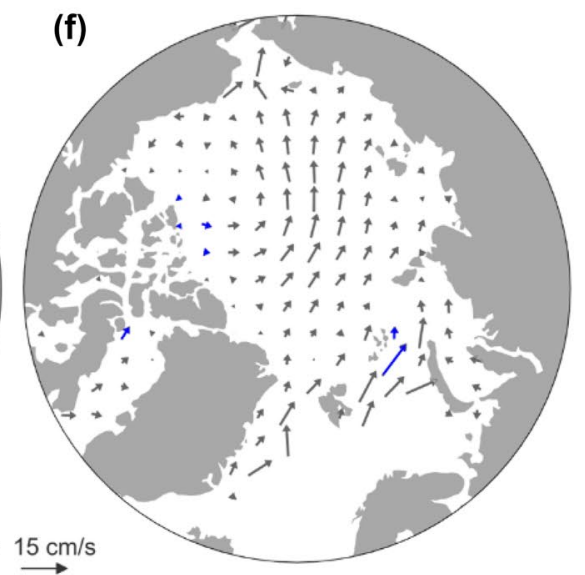

Fig. 14 Composite fields of winter (October-March) $10 \mathrm{~m}$ wind (vectors) and SLP (colors) for years of $\mathbf{a}+\mathrm{ARP}, \mathbf{b}-\mathrm{ARP}$ and $\mathbf{c}$ their difference (a, b) during 1995/96-2011/12. d-f Are the same as a-c, but for winter ice motion. The unit of the scale bar in a-c is (hPa). Blue vectors in $\mathbf{f}$ are the differences of ice motion speed significant at $90 \%$ confidence level 
Accordingly, the change of the source region of sea ice outflow, which is probably related to the regime shift of atmospheric circulation, played an important role in the regime shift of Fram Strait ice export. Besides, sea ice thickness in most part of the Arctic Ocean marginal seas, especially in the Chukchi Sea and Beaufort Sea, also decreased substantially. Thus the decrease in ice thickness and the shift of atmospheric circulation combined to reduce sea ice export since the mid-1990s. As to the causes of the regime shift in atmospheric circulation pattern, i.e., whether it is originated from the global warming-induced sea ice decline or it is just a kind of natural variability, further studies are needed.

This regime shift of ice export may have significant implications for understanding the role of Fram Strait ice export in Arctic sea ice changes. As reviewed at the beginning of this paper, Fram Strait ice export largely contributed to the changes of total Arctic sea ice mass, in particular multiyear ice, before reaching its maximum in the mid-1990s (Lindsay and Zhang 2005). Since then, the amount of ice export has been greatly diminishing with lower interannual variability than before. Under these circumstances, was the contribution of Fram Strait ice export to the variability and changes of Arctic Basin sea ice cover still as great as before? Detailed discussion will be given in the next section.

\section{Connection between the regime shift in ice export and Arctic sea ice change}

To investigate the connection between the regime shift in Fram Strait ice export and the changes of Arctic sea ice inside the basin, composite fields of Arctic basin-wide monthly winter ice thickness and ice drift velocity in extreme ice export months during 1979/1980-1994/1995 (Fig. 15) and 1995/1996-2011/2012 (Fig. 16) were analyzed. The criterion of \pm 1.0 standard deviation was used to define the extremes of ice export. Totally, there are 19 (16) and 18 (15) extreme high (low) ice export months
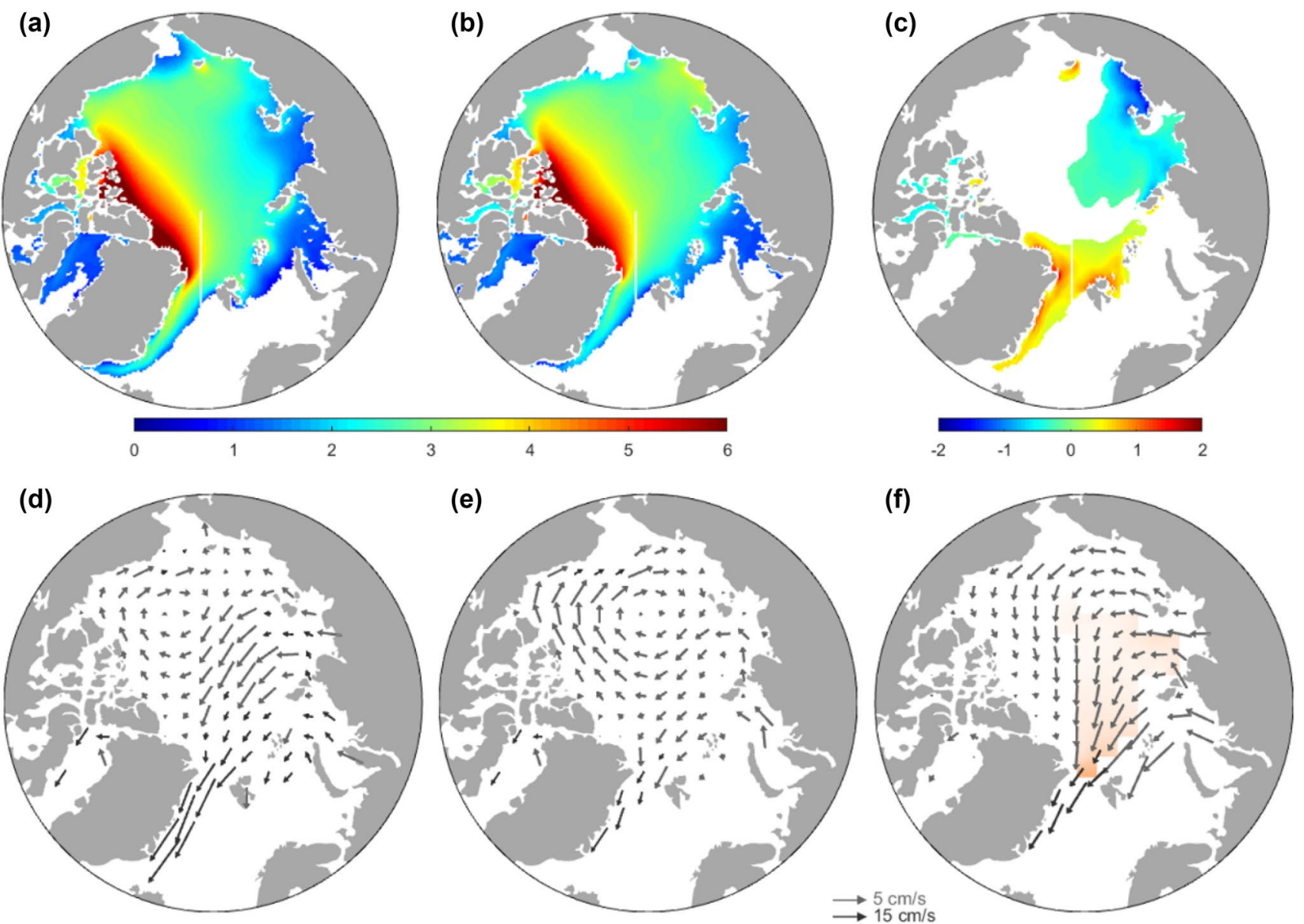

Fig. 15 Composite fields of 1979/1980-1994/1995 monthly winter (October-March) sea ice thickness in a extreme high ice export months, b extreme low ice export months and $\mathbf{c}$ their difference (a, b). d-f Are the same as a-c, but for sea ice motion velocity. The unit of the scale bar in $\mathbf{a}-\mathbf{c}$ is $(\mathrm{m})$. Colors in $\mathbf{c}$ and shaded vectors in $\mathbf{f}$ show the difference of ice thickness and ice motion vectors that are significant at $90 \%$ confidence level 

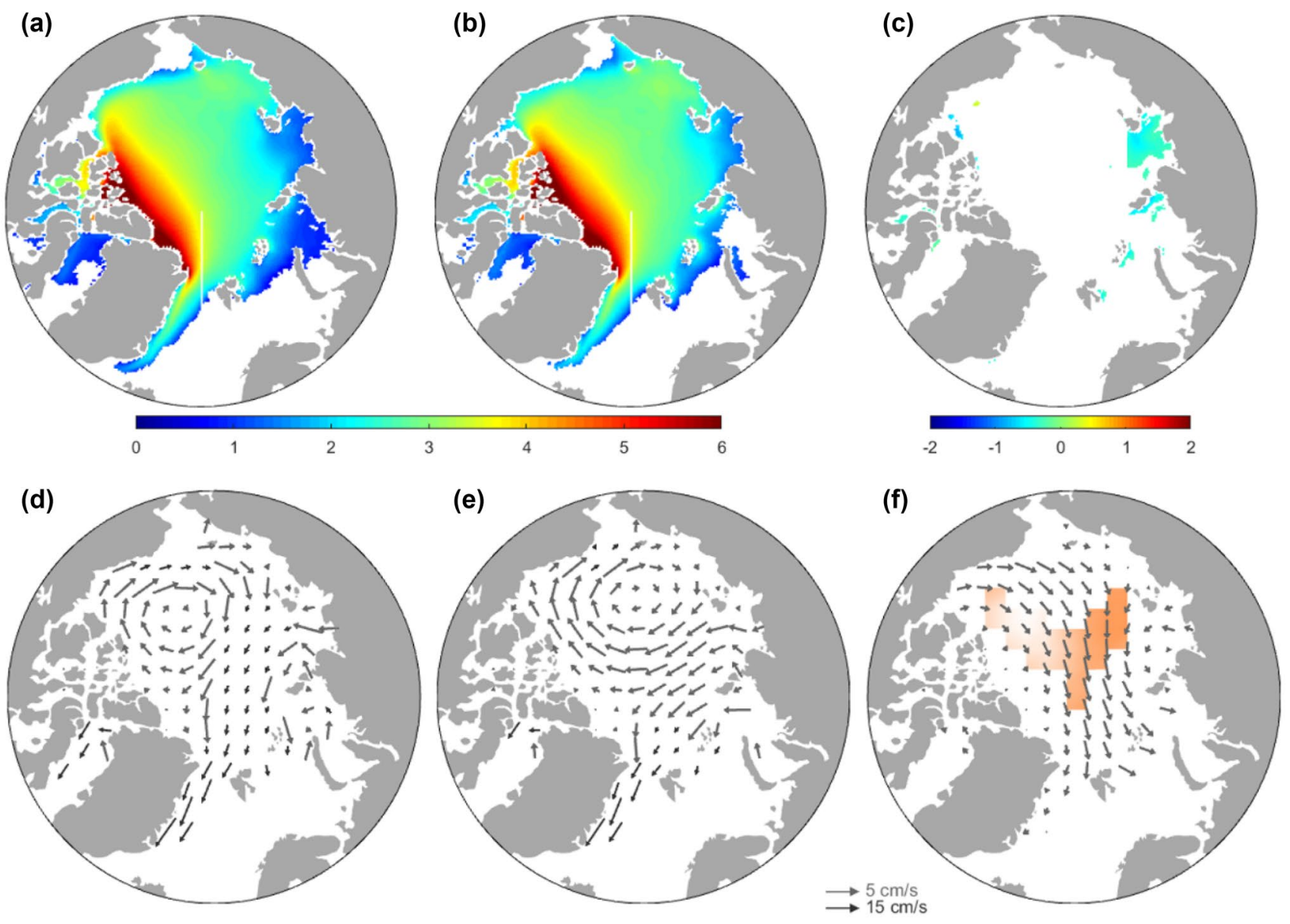

Fig. 16 Same as Fig. 15, but for the period of 1995/1996-2011/2012

before and after 1994/95. In this study, no significant difference of Arctic sea ice concentration between high and low ice export months was found either before or after the regime shift. Thus the case of ice concentration is not given here.

Before the regime shift, sea ice concentrated in the western East Siberian Sea and the Laptev Sea was significantly thinner during high ice export years compared to low ice export years (Fig. 15a-c). The Beaufort gyre was weakened and the Transpolar Drift Stream was stronger in high ice export years than in low ice export years (Fig. 15d-f). By comparison, after the regime shift, almost no significant difference of ice thickness was found between high and low ice export years (Fig. 16a-c). Thus the contributions of sea ice export to the changes in Arctic sea ice thickness are quite different before and after 1994/1995. This influence has been greatly weakened after the regime shift, due to the lower amount and less interannual variation of total Fram strait ice export. Figure 15 again indicates that Arctic sea ice flowing into Fram Strait mainly comes from the East Siberian Sea, Laptev Sea and part of the central Arctic Ocean before mid-1990s. Those regions are the main source regions for the ice flowing into the Nordic Seas.

To further explore how the contributions of Fram Strait ice export to the basin-wide changes of Arctic sea ice dynamically vary with time, monthly ice thickness and ice velocity anomalies were regressed upon the normalized monthly ice export with different lag months relative to the ice export before and after the regime shift around 1994/1995. In this study, no significant correlation between ice export and ice concentration within the Arctic Basin was found for different lag months. Besides, the regression maps of sea ice velocity show only small regions with significant results. Thus the cases of ice concentration and ice velocity are not given here.

Before the regime shift, more ice export could induce great thinning of sea ice located in the eastern Arctic (especially in the East Siberian Sea and the Laptev Sea) during the following several months (Fig. 17), and vice versa, which could directly lead to the changes of total sea ice volume inside the basin. We can clearly recognize how the contributions of Fram Strait ice export onto the 

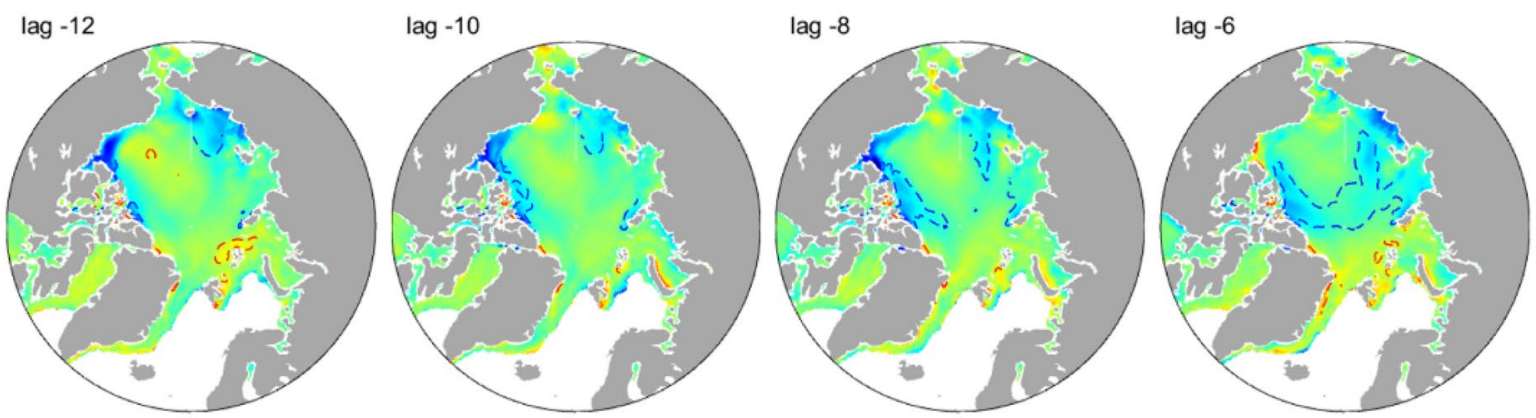

0.25
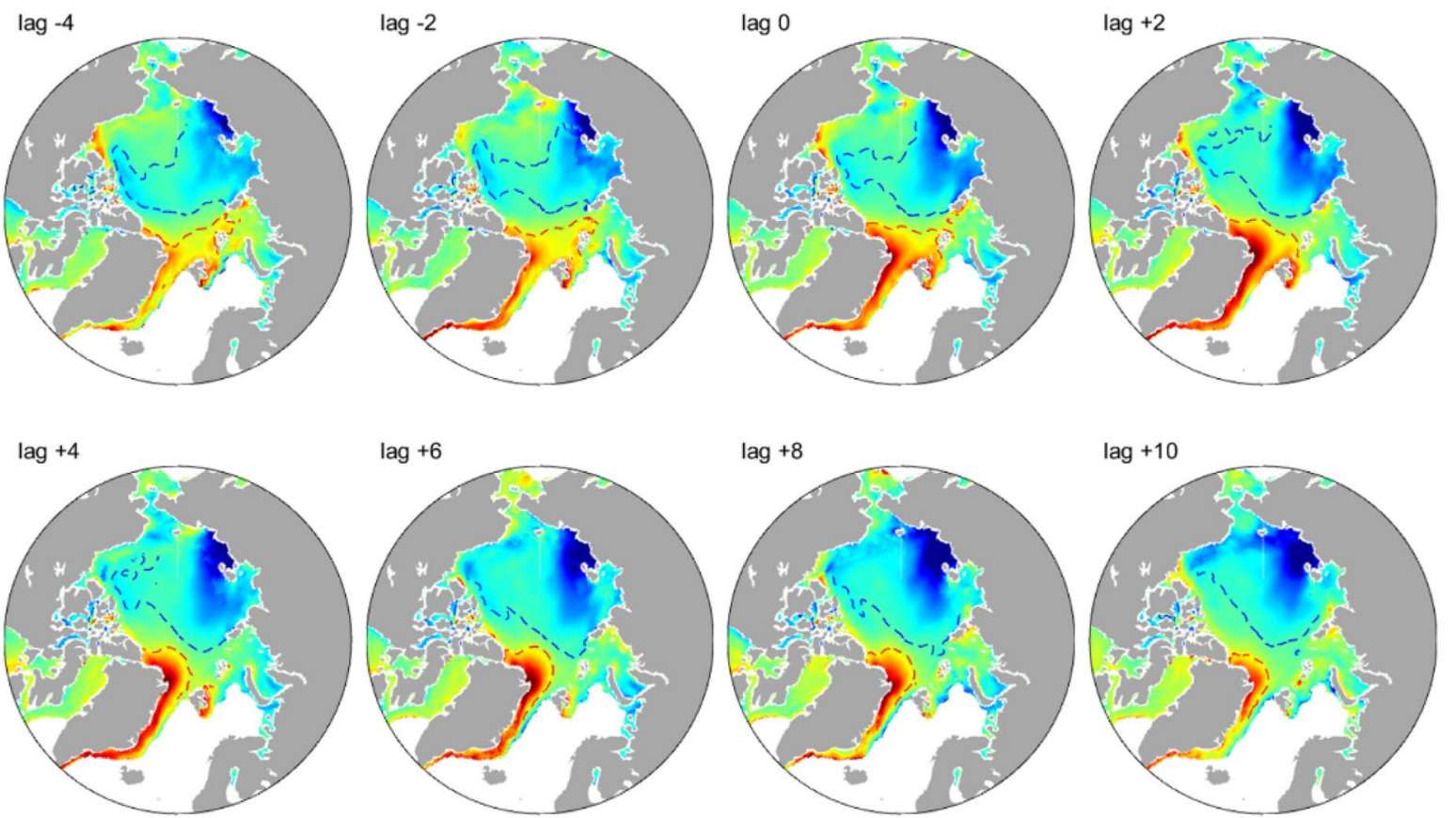

Fig. 17 Lag regression maps of 1979/1980-1994/1995 monthly sea ice thickness anomalies onto the normalized monthly Fram Strait sea ice export. Shaded areas enclosed by dashed lines denote significant

changes of Arctic Basin sea ice dynamically vary with time from these regression maps. Obviously, this kind of impact was very weak after mid-1990s based on the very low regression coefficients in Fig. 18, especially with lag months larger than +4 . It is found that the variability of winter ice export explains $12.6 \%$ of the variability of Arctic basin sea ice volume in the following September before the mid-1990s. Since then, the contribution decreases to $2.50 \%$, quantitatively indicating the reduced influence of Fram Strait ice export onto the variability of total sea ice volume inside the Arctic Basin. The distinct results indicate that the physical mechanisms of recent Arctic sea ice retreat are temporally dependent, with greater impact from Fram Strait ice export before mid-1990s, and more significant influence from thermodynamic processes within the basin since then, such as more incoming solar radiation and the intense ice melting related to the positive values at $90 \%$ confidence level. The numbers in the upper-left corner of each sub-graph denote the lag months of ice thickness. The unit of the scale bar is $(\mathrm{m})$

ice-albedo feedback (Perovich et al. 2007; Markus et al. 2009; Stroeve et al. 2014).

The relation between ice export and the changes of Arctic sea ice drift motion was much weaker than that of Arctic sea ice thickness both before and after the regime shift (figures omitted). The weak relationship between them shows that local atmospheric or oceanic processes, rather than the sea ice export through Fram Strait, are responsible for the changing patterns of Arctic basin-wide sea ice motion. Kwok et al. (2009) also gave a similar conclusion based on satellite observations. Although focused on the sea ice area export, they pointed out that the melting of first-year ice during the summer, rather than the ice export through Fram Strait, dominated the depletion of total Arctic sea ice cover in recent years.

Overall, the associated dynamical processes of the interaction between changes of Fram Strait ice export and 

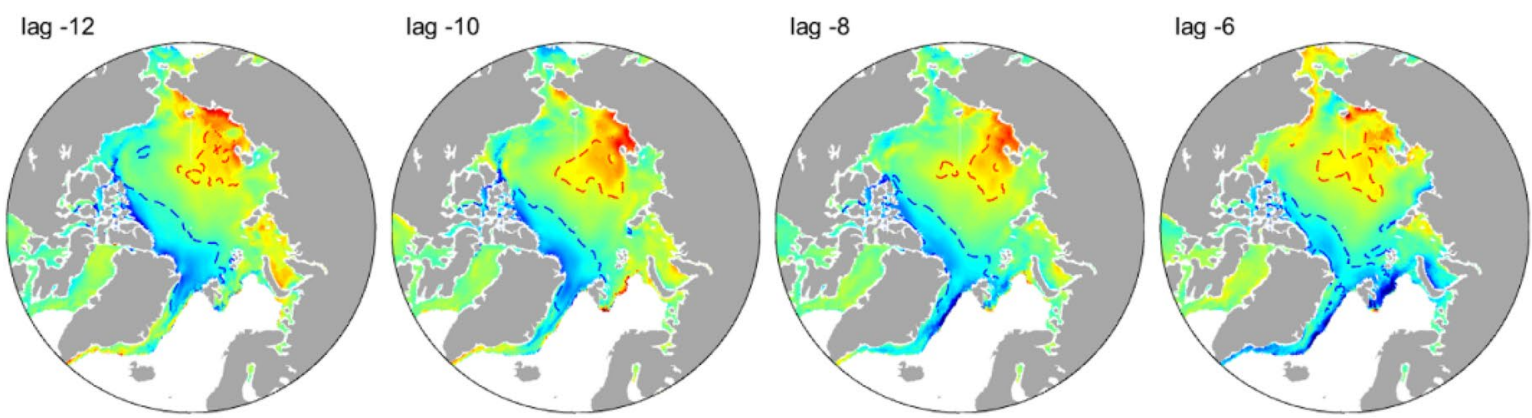

lag -4

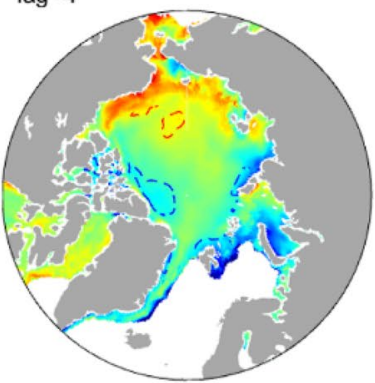

lag -2
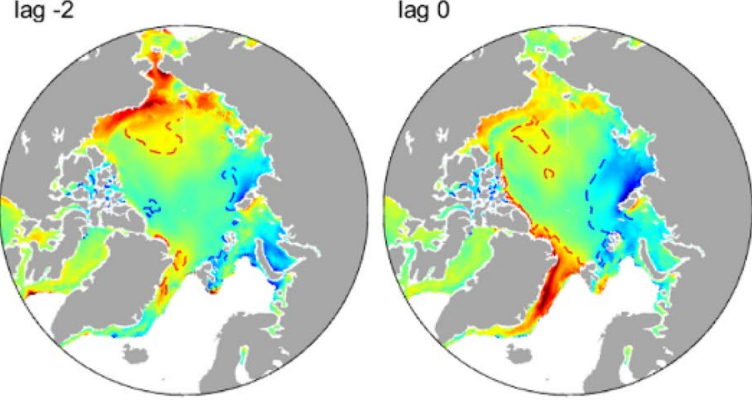

lag +2

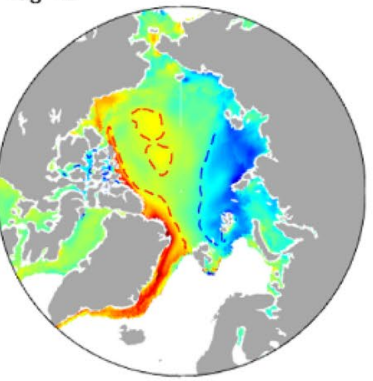

$\operatorname{lag}+8$
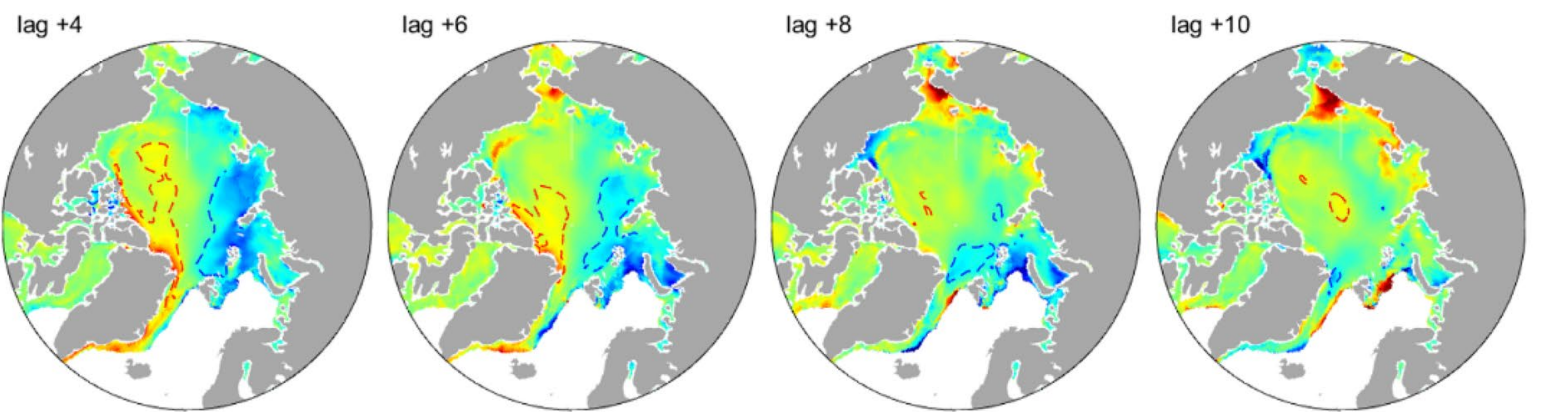

Fig. 18 Same as Fig. 17, but for lag regression maps of 1995/1996-2011/2012

the sea ice mass balance in the Arctic Basin are kind of complicated. On one hand, the long-term retreat of Arctic sea ice cover has lowered the mean ice thickness in the whole Arctic Basin, which could be a precondition for the regime shift of ice export. The change of source region for the sea ice outflowing through the strait (related to the transition of the atmospheric circulation, as mentioned in Sect. 4) induces the lower mean ice thickness within the strait, leading to the abrupt change of ice export together with the precondition.

On the other hand, the impact of changing Fram Strait ice export onto the Arctic Basin ice thickness is a relatively shorter term process. When more ice (most of them is multiyear ice) is exported from the Arctic Basin, the area of open water increases and more new ice is produced, lowering the mean thickness and the total Arctic sea ice volume in the basin (especially in the source region of outflowing ice). Obviously, since 1994/95, this kind of connection has been weakened, which is the main concern in this study.

\section{Conclusions}

A high-resolution global ocean and sea-ice model MIT$\mathrm{gcm}-\mathrm{ECCO} 2$ has been used to estimate the variability and changes of Arctic sea ice export through Fram Strait during 1979-2012, as well as their relationship with recently accelerated Arctic sea ice retreat. In this study, sea ice volume export through Fram Strait demonstrates great daily variability induced by the strong dependence of sea ice motion on daily atmospheric forcing. The seasonal cycle of sea ice export is significant, which is closely related to the seasonal changes of Arctic sea ice and surface wind strength over the strait. The mean annual ice export during our study period amounts to $3216 \mathrm{~km}^{3} /$ year, which is about $12.7 \%$ of the 34 -year averaged annual Arctic sea ice volume, with the maximum and minimum occurring in $1994 / 1995$ and $1984 / 1985$, respectively. Winter ice export shows higher amount and interannual variation than in summer. Variability and changes of ice export are 
dominantly controlled by both sea ice thickness and meridional ice drift velocity across the strait. The correlations between winter (October-March) ice meridional velocity/ ice thickness and winter ice export are $+0.73 /+0.59$ (both passing $99 \%$ confidence level).

Our results suggest that there was a significant regime shift of annual, winter and summer sea ice export through Fram Strait in the mid-1990s. Annual ice export was much higher (with the mean annual export of $3940 \mathrm{~km}^{3}$ per year) and the interannual variability was also greater from $1988 / 1989$ to $1994 / 1995$, while the export was much lower from 1994/1995 to 2011/2012 (with averaged $2965 \mathrm{~km}^{3}$ each year). This study indicates that the regime shift of atmospheric circulation played an important role in the regime shift of Fram Strait sea ice export. Since the mid1990s the large-scale atmospheric circulation pattern in the Northern Hemisphere has shifted from conventional AO to a dipole-structure Arctic Rapid change Pattern (ARP) pattern (Zhang et al. 2008). The more meridional wind anomalies associated with ARP tended to dominate the main patterns of Arctic sea ice motion inside the basin and changed the source region of sea ice outflowing through the strait. In winters with highly positive ARP index, the anticyclonic circulation was limited to the Beaufort Sea. Sea ice outflowing into the Nordic Seas was from both the central Arctic and the Eurasian coast driven by the strong winds from the Pacific sector and Eurasia. On the contrary, when the ARP stayed in its negative phase, the weakened northerly winds north of Greenland and Fram Strait greatly constrained the ice exporting from central Arctic to the strait. In this study, ARP transitions to a generally, decadal-scale negative phase after 1995/1996 with more frequent occurrence of large negative polarity, which could primarily explain the significant reduction of sea ice export in recent years.

Moreover, the impact of changes in Fram Strait sea ice export on the Arctic basin-wide sea ice has been greatly weakened after the regime shift around mid-1990s. Since the total Arctic sea ice volume remained declining through the entire study period, we can speculate that the recent Arctic basin-wide sea ice loss was mainly induced by the accelerated ice melting process in the Arctic Basin, rather than the ice outflow into Nordic Seas through Fram Strait. This study quantitatively indicates that the influence of Fram Strait ice export onto the variability of total sea ice volume inside the Arctic Basin has been reduced since mid-1990s. More investigations are needed to understand and quantify the contributions from ice export on the Arctic sea ice volume.

Acknowledgements This work was supported by the National Key R\&D Program of China (2016YFA0601804) and the Ministry of Science and Technology of China (Grant 2015CB953900). ZW was supported by "the Fundamental Research Funds for the Central Universities" (2017B20714; 2017B04814). XZ was supported by the U.S. NSF
Grant \#1023592 and partially by the Korean Polar Research Institute project KPOPS.

Open Access This article is distributed under the terms of the Creative Commons Attribution 4.0 International License (http://creativeco mmons.org/licenses/by/4.0/), which permits unrestricted use, distribution, and reproduction in any medium, provided you give appropriate credit to the original author(s) and the source, provide a link to the Creative Commons license, and indicate if changes were made.

\section{References}

Bi H, Sun K, Zhou X, Huang H, Xu X (2016) Arctic Sea ice area export through the Fram Strait estimated from satellite-based data: 1988-2012. IEEE J Sel Top Appl Earth Obs Remote Sens 9:3144-3157. https://doi.org/10.1109/jstars.2016.2584539

Carmack EC, Yamamoto-Kawai M, Haine TWN et al (2016) Freshwater and its role in the Arctic Marine system: sources, disposition, storage, export, and physical and biogeochemical consequences in the Arctic and global oceans. J Geophys Res Biogeosci 121:675-717. https://doi.org/10.1002/2015jg003140

Cavalieri D, Parkinson C (2012) Arctic sea ice variability and trends, 1979-2010. The Cryosphere 6:881-889. https://doi. org/10.5194/tcd-6-881-2012

Cohen J, Screen JA, Furtado JC et al (2014) Recent Arctic amplification and extreme mid-latitude weather. Nat Geosci 7:627-637. https://doi.org/10.1038/ngeo2234

Comiso JC (2012) Large decadal decline of the Arctic multiyear ice cover. J Clim 25:1176-1193. https://doi.org/10.1175/JCLID-11-00113.1

Comiso JC (2015) Bootstrap sea ice concentrations from Nimbus-7 SMMR and DMSP SSM/I-SSMIS, version 2. Boulder, NASA National Snow and Ice Data Center Distributed Active Archive Center, Colorado.

Comiso JC, Parkinson C, Gersten R, Stock L (2008) Accelerated decline in the Arctic sea ice cover. Geophys Res Lett. https:// doi.org/10.1029/2007GL031972

Day JJ, Hargreaves JC, Annan JD, Abe-Ouchi A (2012) Sources of multi-decadal variability in Arctic sea ice extent. Environ Res Lett 7:034011. https://doi.org/10.1088/1748-9326/7/3/034011

Dickson RR, Meincke J, Malmberg SA, Lee AJ (1988) The "Great Salinity Anomaly" in the northern North Atlantic 1968-1982. Prog Oceanogr 20:103-151. https://doi.org/10.1016/00796611(88)90049-3

Hakkinen S, Proshutinsky A, Ashik I (2008) Sea ice drift in the Arctic since the 1950s. Geophys Res Let 35(L19704). https:// doi.org/10.1029/2008GL034791

Hilmer M, Jung T (2000) Evidence for a recent change in the link between the North Atlantic Oscillation and Arctic sea ice. Geophys Res Lett 27:989-992. https://doi.org/10.1029/1999g10109 44

Holland M, Finnis J, Serreze MC (2006) Simulated Arctic Ocean freshwater budgets in the twentieth and twenty-first centuries. J Clim 19:6221-6242. https://doi.org/10.1175/JCLI3967.1

Koenigk T, Mikolajewicz U, Haak H, Jungclaus JH (2006) Variability of Fram Strait sea ice export: causes, impacts and feedbacks in a coupled climate model. Clim Dyn 26:17-34. https://doi. org/10.1007/s00382-005-0060-1

Krumpen T, Gerdes R, Haas C et al (2016) Recent summer sea ice thickness surveys in Fram Strait and associated ice volume fluxes. The Cryosphere 10:523-534. https://doi.org/10.5194/ tc-10-523-2016 
Kwok R (2000) Recent changes in Arctic Ocean sea ice motion associated with the North Atlantic Oscillation. Geophys Res Lett 27:775-778. https://doi.org/10.1029/1999g1002382

Kwok R (2009) Outflow of Arctic Ocean Sea Ice into the Greenland and Barents Seas: 1979-2007. J Clim 22:2438-2457. https:// doi.org/10.1175/2008jcli2819.1

Kwok R, Rothrock D (2009) Decline in Arctic sea ice thickness from submarine and ICESat records: 1958-2008. Geophys Res Lett 36:L15501. https://doi.org/10.1029/2009g1039035

Kwok R, Cunningham GF, Pang SS (2004) Fram Strait sea ice outflow. J Geophys Res 109:C01009. https://doi.org/10.1029/2003j c001785

Kwok R, Cunningham GF, Wensnahan M et al (2009) Thinning and volume loss of the Arctic Ocean sea ice cover: 2003-2008. J Geophys Res Ocean 114(C7). https://doi.org/10.1029/2009j c005312

Kwok R, Spreen G, Pang S (2013) Arctic sea ice circulation and drift speed: decadal trends and ocean currents. J Geophys Res Ocean 118:2408-2425. https://doi.org/10.1002/jgrc.20191

Langehaug HR, Geyer F, Smedsrud LH, Gao Y (2013) Arctic sea ice decline and ice export in the CMIP5 historical simulations. Ocean Model 71:114-126. https://doi.org/10.1016/j.ocemo d.2012.12.006

Laxon S, Giles K, Ridout A et al (2013) CryoSat-2 estimates of Arctic sea ice thickness and volume. Geophys Res Lett 40(4):732-737. https://doi.org/10.1002/grl.50193

Lee H, Kwon M, Yeh S et al (2017) Impact of Poleward moisture transport from the North Pacific on the Acceleration of Sea Ice Loss in the Arctic since 2002. J Clim 30:6757-6769. https://doi. org/10.1175/jcli-d-16-0461.1

Lindsay RW, Schweiger A (2015) Arctic sea ice thickness loss determined using subsurface, aircraft, and satellite observations. The Cryosphere 9:269-283. https://doi.org/10.5194/tc-9-269-2015

Lindsay RW, Zhang J (2005) The thinning of Arctic Sea Ice, 19882003: have we passed a tipping point? J Clim 18(22):4879-4894. https://doi.org/10.1175/jcli3587.1

Losch M, Menemenlis D, Campin J et al (2010) On the formulation of sea-ice models. Part 1: Effects of different solver implementations and parameterizations. Ocean Model 33:129-144. https:// doi.org/10.1016/j.ocemod.2009.12.008

Markus T, Stroeve JC, Miller J (2009) Recent changes in Arctic sea ice melt onset, freezeup, and melt season length. J Geophys Res. https://doi.org/10.1029/2009JC005436

Marshall J, Adcroft A, Hill C et al (1997a) A finite-volume, incompressible Navier Stokes model for studies of the ocean on parallel computers. J Geophys Res Ocean 102(C3):5753-5766. https://doi. org/10.1029/96jc02775

Marshall J, Hill C, Perelman L, Adcroft A (1997b) Hydrostatic, quasihydrostatic, and nonhydrostatic ocean modeling. J Geophys Res Ocean 102(C3):5733-5752. https://doi.org/10.1029/96jc02776

Maslanik J, Drobot S, Fowler C, Emery W, Barry R (2007) On the Arctic climate paradox and the continuing role of atmospheric circulation in affecting sea ice conditions. Geophys Res Lett 34:L03711. https://doi.org/10.1029/2006gl028269

Menemenlis D, Fukumori I, Lee T (2005a) Using Green's functions to calibrate an ocean general circulation model. Mon Weather Rev 133(5):1224-1240. https://doi.org/10.1175/mwr2912.1

Menemenlis D, Hill C, Adcrocft A et al (2005b) NASA supercomputer improves prospects for ocean climate research. EOS Trans AGU 86(9):89-96. https://doi.org/10.1029/2005eo090002

Menemenlis D, Campin J, Heimbach P et al (2008) ECCO2: High resolution global ocean and sea ice data synthesis. Mercat Ocean Q News1 31:13-21

Nguyen AT, Menemenlis D, Kwok R (2011) Arctic ice-ocean simulation with optimized model parameters: approach and assessment. J Geophys Res 116(C4). https://doi.org/10.1029/2010JC006573
Onogi K, Tsutsui J, Koide H et al (2007) The JRA-25 reanalysis. J Meteorol Soc Jpn 85(3):369-432. https://doi.org/10.2151/ jmsj.85.369

Overland J, Wang M (2005) The Arctic climate paradox: the recent decrease of the Arctic Oscillation. Geophys Res Lett 32:L06701. https://doi.org/10.1029/2004g1021752

Overland J, Wang M (2010) Large-scale atmospheric circulation changes are associated with the recent loss of Arctic sea ice. Tellus A 62(1):1-9. https://doi.org/10.3402/tellusa.v62i1.15661

Perovich D, Light B, Eicken H, Jones K, Runciman K, Nghiem S (2007) Increased solar heating of the Arctic Ocean and adjacent seas, 1979-2005: attribution and role in the ice-albedo feedback. Geophys Res Lett 34:L19505. https://doi.org/10.1029/2007G L031480

Rampal P, Weiss J, Marsan D (2009) Positive trend in the mean speed and deformation rate of Arctic sea ice, 1979-2007. J Geophys Res Ocean (1978-2012) 114(C5):C05013. https://doi. org/10.1029/2008jc005066

Ricker R, Girard-Ardhuin F, Krumpen T, Lique C (2018) Satellitederived sea ice export and its impact on Arctic ice mass balance. Cryosphere 12(9):3017-3032. https://doi.org/10.5194/ tc-12-3017-2018

Rigor I, Wallace J (2004) Variations in the age of Arctic sea-ice and summer sea-ice extent. Geophys Res Lett 31::L09401. https://doi. org/10.1029/2004gl019492

Rigor I, Wallace J, Colony R (2002) Response of sea ice to the Arctic Oscillation. J. Clim 15:2648-2663. https://doi.org/10.1175/15200442(2002)015\%3C2648:rositt\%3E2.0.co;2

Rothrock D, Percival D, Wensnahan M (2008) The decline in arctic sea-ice thickness: Separating the spatial, annual, and interannual variability in a quarter century of submarine data. J Geophys Res Ocean 113:C05003. https://doi.org/10.1029/2007jc004252

Schutz B, Zwally H, Shuman C et al (2005) Overview of the ICESat Mission. Geophys Res Lett 32:L21S01. https://doi. org/10.1029/2005gl024009

Screen JA, Simmonds I, Deser C, Tomas R (2013) The atmospheric response to three decades of observed Arctic sea-ice loss. J Clim 26:1230-1248. https://doi.org/10.1175/jcli-d-12-00063.1

Serreze M, Barrett A, Slater A et al (2006) The large-scale freshwater cycle of the Arctic. J Geophys Res Ocean 111(C11). https://doi. org/10.1029/2005jc003424

Smedsrud LH, Sirevaag A, Kloster K, Sorteberg A, Sandven S (2011) Recent wind driven high sea ice area export in the Fram Strait contributes to Arctic sea ice decline. Cryosphere 5:821-829. https ://doi.org/10.5194/tc-5-821-2011

Smedsrud LH, Halvorsen MH, Stroeve JC, Zhang R, Kloster K (2017) Fram Strait sea ice export variability and September Arctic sea ice extent over the last 80 years. The Cryosphere 11:65-79. https ://doi.org/10.5194/tc-11-65-2017

Spreen G (2008) Satellite-based estimates of sea ice volume flux: Applications to the Fram Strait region. Ph.D. thesis, Inst. of Oceanogr., Univ. of Hamburg, Hamburg, Germany. http://ediss .sub.uni-hamburg.de/volltexte/2008/3776/

Spreen G, Kern S, Stammer D, Hansen E (2009) Fram Strait sea ice volume export estimated between 2003 and 2008 from satellite data. Geophys Res Lett 36:L19502. https://doi.org/10.1029/2009g 1039591

Spreen G, Kwok R, Menemenlis D (2011) Trends in Arctic sea ice drift and role of wind forcing: 1992-2009. Geophys Res Lett 38:L19501. https://doi.org/10.1029/2011g1048970

Steele M, Morley R, Ermold W (2001) PHC: a global ocean hydrography with a high-quality Arctic Ocean. J Clim 14:2079-2087. https://doi.org/10.1175/1520-0442(2001)014\%3C2079:pagoh w\%3E2.0.co;2

Stroeve JC, Serreze M, Holland M, Kay J, Maslanik J, Barrett A (2012) The Arctic's rapidly shrinking sea-ice cover: a research 
synthesis. Clim Chang 110:1005-1027. https://doi.org/10.1007/ s10584-011-0101-1

Stroeve JC, Markus T, Boisvert L, Miller J, Barrett A (2014) Changes in Arctic melt season and implications for sea ice loss. Geophys Res Lett 41:1216-1225. https://doi.org/10.1002/2013GL058951

Swart NC, Fyfe JC, Hawkins E, Kay JE, Jahn A (2015) Influence of internal variability on Arctic sea-ice trends. Nat Clim Chang 5(2):86-89. https://doi.org/10.1038/nclimate2483

Thompson D, Wallace J (1998) The Arctic oscillation signature in the wintertime geopotential height and temperature fields. Geophys Res Lett 25:1297-1300. https://doi.org/10.1029/98g100950

Tschudi M, Fowler C, Maslanik J, Stewart JS, Meier W (2016) Polar pathfinder daily $25 \mathrm{~km}$ EASE-grid sea ice motion vectors, Version 3. Boulder, NASA National Snow and Ice Data Center Distributed Active Archive Center, Colorado

Vihma T (2014) Effects of Arctic sea ice decline on weather and climate: a review. Surv Geophys 35:1175-1214. https://doi. org/10.1007/s10712-014-9284-0

Vinje T, Nordlund N, Kvambekk A (1998) Monitoring ice thickness in Fram Strait. J Geophys Res Oceans 103:10437-10449. https:// doi.org/10.1029/97jc03360

Walsh J (2013) Melting Ice: what is happening to arctic sea ice, and what does it mean for us? Oceanography. https://doi.org/10.5670/ oceanog.2013.19

Zhang J, Rothrock DA (2003) Modeling global sea ice with a thickness and enthalpy distribution model in generalized curvilinear coordinates. Mon Weather Rev 131(5):681-697. https
://doi.org/10.1175/1520-0493(2003)131\%3C0845:MGSIW $\mathrm{A} \% 3 \mathrm{E} 2.0 . \mathrm{CO} ; 2$

Zhang X, Ikeda M, Walsh J (2003) Arctic sea ice and freshwater changes driven by the atmospheric leading mode in a coupled sea ice-ocean model. J Clim 16:2159-2177. https://doi. org/10.1175/2758.1

Zhang X, Walsh J, Zhang J et al. (2004) Climatology and Interannual Variability of Arctic Cyclone Activity: 1948-2002. J Clim 17(12):2300-2317. https://doi.org/10.1175/15200442(2004)017\%3C2300:caivoa\%3E2.0.co;2

Zhang X, Sorteberg A, Zhang J, Gerdes R, Comiso J (2008) Recent radical shifts of atmospheric circulations and rapid changes in Arctic climate system. Geophys Res Lett 35:L22701. https://doi. org/10.1029/2008g1035607

Zhang Z, Bi H, Sun K, Huang H, Liu Y, Yan L (2017) Arctic sea ice volume export through the Fram Strait from combined satellite and model data: 1979-2012. Acta Oceanol Sin 36(1):44-55. https ://doi.org/10.1007/s13131-017-0992-4

Zwally HJ, Schutz B, Abdalati W et al (2002) ICESat's laser measurements of polar ice, atmosphere, ocean, and land. J Geodyn 34:405-445. https://doi.org/10.1016/s0264-3707(02)00042-x

Publisher's Note Springer Nature remains neutral with regard to jurisdictional claims in published maps and institutional affiliations. 